\title{
Reading L.M. Montgomery: What Adult Swedish and Canadian Readers Told Us
}

DOI

https://doi.org/10.32393/jlmms/2020.0004

Published on

Wed, 05/13/2020 - 13:24

This article provides an international comparison of the role of reading L.M Montgomery in the lives of adult leisure readers in Sweden and Canada. Our analysis of open-ended qualitative interviews with Canadian readers and written accounts submitted by Swedish readers focuses on ten themes, all linked by the powerful current of emotion evoked in avid Montgomery readers.

Back to top

\section{Introduction}

When one of us, Catherine Ross, gave a talk at the 2018 L.M. Montgomery and Reading conference, she discussed nine themes on reading Montgomery that emerged from her open-ended, qualitative interviews with 307 avid recreational readers in Canada. At the end of the presentation, during questions from the audience, the other of us, Asa Warnqvist, noted that in her own research on reading Montgomery she had collected 303 reader statements from Montgomery readers in Sweden. These readers had responded to Warnqvist's request, posted in libraries in Sweden and in the four major Swedish newspapers, for accounts of readers' experiences reading Montgomery. The concordance of our findings was striking. At the end of the talk, the two of us converged to marvel at the remarkable similarity in the responses between Swedish and Canadian readers. On the spot, we decided to compare the experiences of Swedish and Canadian readers of Montgomery, teasing 
out similarities and possible differences.

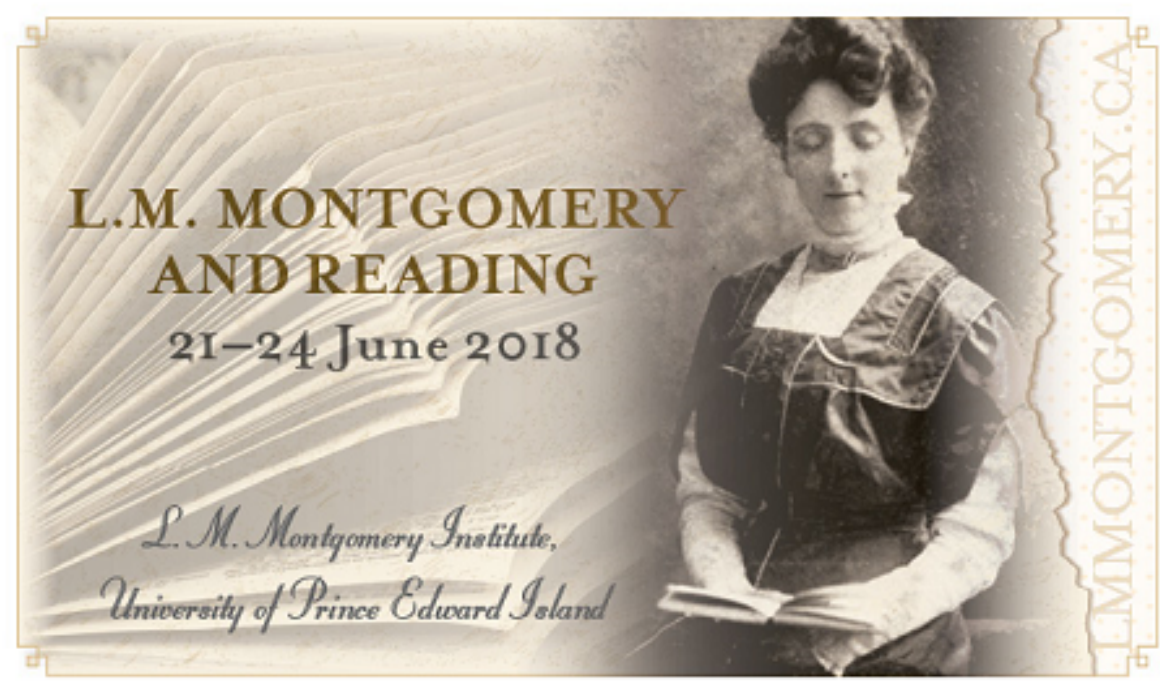

L.M. Montgomery 2018 conference promotional material. 2018. L.M. Montgomery Institute collection.

This article represents a step in an international comparison in which we examine the role reading Montgomery plays in the lives of everyday readers, a topic that hitherto has not attracted much research. Apart from our own studies, 1 published research related to the self-reported experience of larger samples of readers reading Montgomery in specific cultural contexts includes Yoshiko Akamatsu's "Japanese Readings of Anne of Green Gables" 2 and two studies based on Finnish responses to Montgomery. The first Finnish study is a transcribed interview conducted with Suvi Ahola and Satu Koskimies during the 2006 Montgomery conference, Storm and Dissonance; $\underline{3}$ in 2005, Ahola and Koskimies had edited an anthology containing a selection of Finnish readers' responses to Finnish translations of Montgomery's novels. 4 The second is a perceptive analysis by Vappu Kannas of the anthologized set of Finnish readers' responses in which she emphasizes the affective dimension of reading. $\underline{5}$

Pleasure reading, or leisure reading, is generally defined as voluntary reading that readers engage in for their own enjoyment, as opposed to assigned reading or reading undertaken for purposes of work. $\underline{6}$ Reading for pleasure-especially reading fiction-has until quite recently been regarded with suspicion similar to the view held by Valancy's mother in The Blue Castle (1926), who believed that "a book that 
was enjoyable was dangerous," although she admitted it might be somewhat permissible to read improving non-fiction. 7 A small but growing body of work focuses on the experience of reading fiction for pleasure and on the importance of such reading in the lives of readers. Recent decades have turned cultural theory toward recognizing the affective dimension in the reception process. One of the strongest advocates of this turn is Rita Felski, who, in her influential study Uses of Literature (2009), champions a positive and embracing aesthetics, in contrast with what she considers the aesthetic narrowness that occurs when critics focus exclusively on critical reading and are blind to the heterogeneous ways in which readers engage with a literary text. Felski argues the motives for reading are manifold, and they all deserve recognition, whether they stem from a desire for knowledge or for a longing to escape. $\underline{8}$

The work of reader-response theorists such as Felski as well as groundbreaking empirical studies with everyday readers, such as Janice Radway's Reading the Romance (1984), are changing the way pleasure reading is looked upon in scholarly research in a number of disciplines including literary studies, library and information science, histoire du livre, and psychology. $\underline{9}$ Through a range of disciplinary lenses, reading researchers have examined the various roles that leisure reading serves in the lives of readers: from enhancing self-understanding to gaining cognitive insights to fostering empathy with others. For example, work on leisure reading and empathy by the research group led by Toronto cognitive psychologists Keith Oatley and Raymond Mar supports claims commonly expressed by readers who say that they become the characters they read about.10

Our study joins the body of interdisciplinary work that examines pleasure reading in everyday readers' lives. Unlike reception and reader-response theorists such as Jonathan Culler, Stanley Fish, Wolfgang Iser, Hans Robert Jauss, and others, we are interested in living, breathing readers and their reported reading experiences, not in implied readers as inferred from a critic's close examination of the text. For researchers studying such actual readers, Louise Rosenblatt's classic text Literature as Exploration (1938) offers a useful theoretical framework of reading as a transaction between an active reader and a text. As Rosenblatt puts it, the reader "brings to the work personality traits, memories of past events, present needs and preoccupations, a particular mood of the moment, and a particular physical condition. These and many other elements, in a never-to-be duplicated combination, determine his response to the peculiar contribution of the text." 11 
To understand reading experience, situated as it is in the lives of readers, we needed to collect stories of reading that are rich in details and contextualized, as much as possible, in the reader's life. We used qualitative research methods to elicit these accounts-open-ended interviews with the Canadian readers and open-ended written statements from the Swedish readers. We did not ask them to respond to researcher-generated questions, standardized across all readers. Instead, we gave our readers an invitation to talk about or write about whatever aspect of reading Montgomery was important and salient to them. Our Canadian and Swedish readers generously told us stories about their Montgomery reading. In presenting and analyzing these accounts from readers, our intention is to give a starring role to the voices of readers. Accordingly, in the analysis that follows, we quote freely from these voices in order to provide a grounded discussion of the range of ways in which Montgomery fans from two countries respond to and remember her novels.

Back to top

\section{Two Nations Reading Montgomery, Two Methods of Data Collection}

Empirical studies of pleasure readers can be sorted according to the methods used to collect the data. The largest body of such research uses researcher-generated, standardized survey questions administered to large national samples of readers, randomly chosen. These demographic studies typically define a "reader" as someone who has in the past six months voluntarily read a book, in whole or in part, that was not required for work or study. Once readers are sorted from non-book readers, researchers can correlate participation in reading with age, gender, race, level of education, income, library use, book purchasing, and other variables. Because of their large sample size and random selection, these associations can be generalized to the larger population from which the sample was drawn. Such studies are useful in providing the big picture on voluntary reading because they can be used to make statistically significant generalizations about who reads what kinds of materials for how many minutes a day in what part of the world.12 But for a more fine-grained exploration of reading experience, researchers typically use qualitative interviews or open-ended reader accounts, which are then analyzed for patterns of significance that emerge from the data. In some studies, researchers ask readers to respond in a laboratory setting to the same assigned text, a research strategy that 
facilitates comparisons of subjects' responses but sacrifices the element of reader choice, which is at the heart of genuine pleasure reading.

Rarer are studies that focus on the experience of reading materials chosen by readers themselves and read in a natural setting. Groundbreaking, book-length examples of this latter kind of research include Donald Fry's Children Talk About Books (1985), which reports case studies of individual children's reading; Janice Radway's already mentioned Reading the Romance, which uses a combination of individual and group interviews and questionnaires to understand readers' experience of romantic fiction; Elizabeth Long's Book Clubs (2003), an ethnographic study of seventy-seven contemporary women's reading groups in Houston, Texas; Ian Collinson's Everyday Readers (2009), which uses semi-structured interviews with twenty-one readers in order to explore everyday book-reading culture; and Margaret Mackey's One Child Reading (2016), an ethnographic exploration of the making of an avid reader that examines one child's engagement with a variety of texts in the context of a particular time and place.

The studies reported here of Swedish and Canadian Montgomery readers belong in this small group of qualitative, empirical reading studies, in which the material is chosen by the reader and is read for pleasure, not assigned by the researcher. Comparable studies of readers in different countries who have voluntarily read the same material are especially rare. But because so many readers across generations and nations have found Montgomery books deeply meaningful in their lives, we have been able to elicit the responses of many, many readers in Sweden and Canada who have read the same materials-the Anne books (1908-1939), the Emily books (1923-1927), The Blue Castle, and others. The comparison benefits from the fortunate circumstance that books by Montgomery have been available in the two countries for an almost equal amount of time. For example, Anne of Green Gables was translated into Swedish and published in Sweden as early as 1909, the year after the original US publication, making the Swedish translation the very first. The novel and its sequels have also had a lasting appeal to the readers of the two countries and have been reprinted continuously up until the present day.

Back to top

\section{The Swedish Study}


In 2008, Assa Warnqvist placed a call in Swedish libraries and the four major newspapers in Sweden asking Montgomery readers to provide an account of their experience reading Anne of Green Gables and other works by Montgomery. The study was inspired by the Finnish Literature Society's similar project. In 2003 this group had posted a call in Finnish newspapers, on email lists, and online that began, "What have the Anne and Emily books meant for you?" Of the 222 letters received, fifty-seven were selected, all but one from women, for inclusion in an anthology edited by Suvi Ahola and Satu Koskimies.13 In Warnqvist's comparable call to Swedish readers, she asked:

Have you read Anne of Green Gables? ... Write about what Anne of Green Gables or any other work by Montgomery has meant to you. When did you read the book? How old were you? What did you think of it? Was there anything in particular about Anne's personality that caught you? What has this reading experience given you?

The reason the call focused on Anne of Green Gables was that it is the most wellknown of Montgomery's books in Sweden, but the wording did not deter respondents from mentioning other Montgomery books, and they did, particularly the other Anne books and the Emily books.
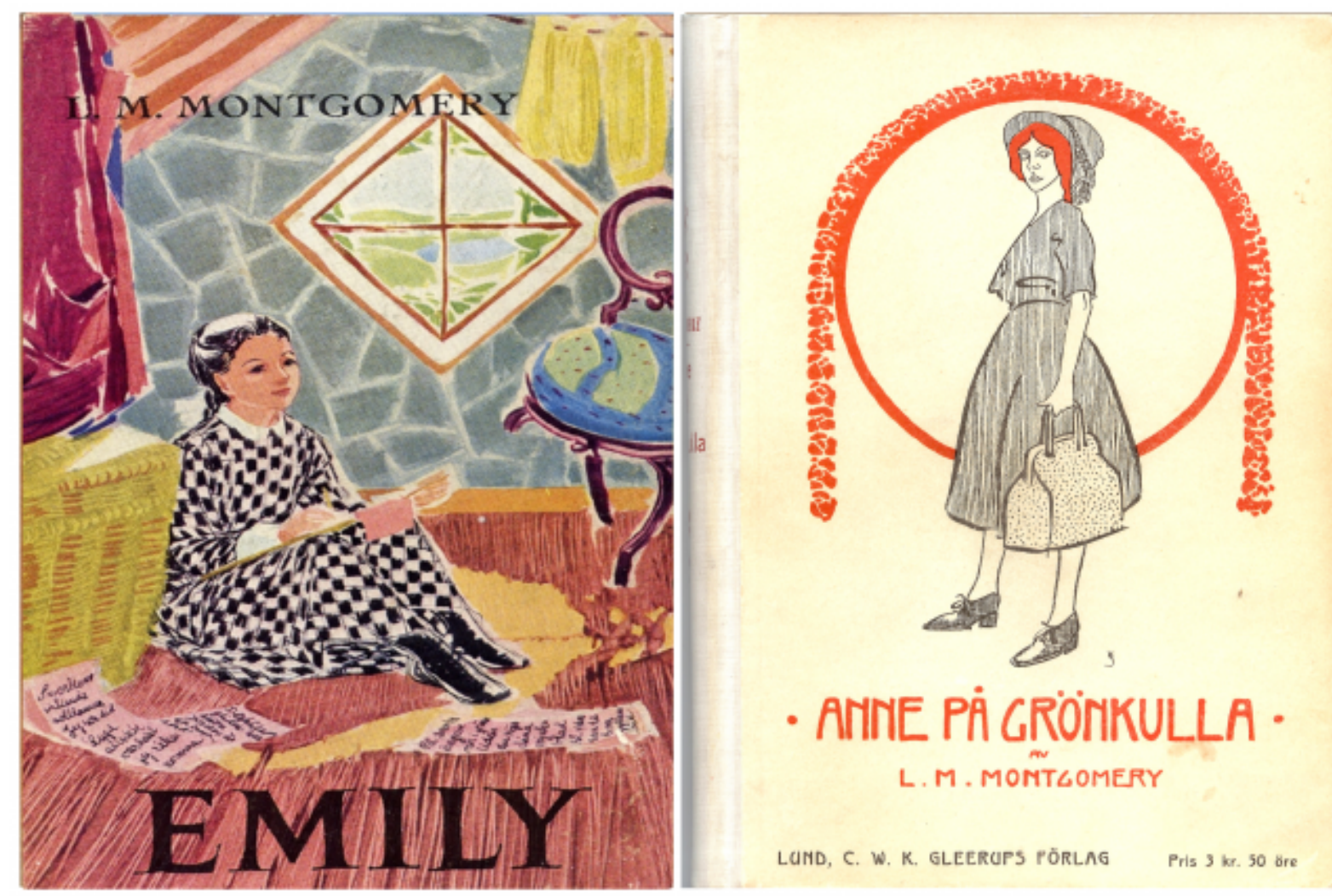
Left: Emily by L.M. Montgomery, cover illustration by Eva Laurell. Gleerups, 1955.

Right: Anne på Grönkulla by L.M. Montgomery, cover illustration by unknown. C.W.K. Gleerups, 1909.

Warnqvist got 303 responses from readers, mostly from girls and women, with the majority born in the 1940s, 1950s, and 1960s. As was to be expected with a book that has been in print for a hundred years, the responses came from readers of different ages. The youngest among them was twelve years old, only recently introduced to Anne, whereas the oldest would soon turn ninety-three. A few of the letters were written by men, and many women and girls who responded included descriptions of brothers, fathers, sons, and other men in their lives who also read and enjoyed Anne of Green Gables. The responses, received both in letter and electronic format, ranged from a few paragraphs to richly detailed accounts as long as ten pages. The responses often mixed childhood memories with adult readers' reflections on the significance of reading and rereading Montgomery over a lifetime.

Because the Swedish readers had more time to consider their responses than is usually the case in a face-to-face interview, some chose to enrich their narratives with various graphic supplements: scans or photographs of their own copies of the books, hand-drawn illustrations of scenes in the books, and various other photographs, linked in one way or another to the readers' experience of reading Anne or Emily. Submitted photographs included one of a large tree growing in a reader's backyard (her Snow Queen), a picture of a reader reading Anne of Green Gables as a child in 1959, and various snapshots taken on readers' trips to Prince Edward Island.

Sixty-five of the 303 responses were published in an anthology, Besläktade själar: Läsupplevelser av Anne på Grönkulla (Kindred Spirits: Reading Experiences of Anne of Green Gables), in conjunction with the one-hundredth anniversary of the Swedish translation of Anne of Green Gables in 2009. The quotations chosen here are English translations taken from the reading responses published in this anthology. 14 The readers are therefore not anonymous and their full names appear adjacent to their quotations.

Back to top 


\section{The Canadian Study}

To investigate the experience of reading for pleasure among Canadian readers, Catherine Ross used open-ended, qualitative interviews conducted with adults who are avid readers and who read for pleasure. In successive offerings over three decades of her course on reading in the Master of Library and Information Science program at Western, Ross and her graduate students have conducted 302 interviews with avid readers. The purpose of these interviews was to find out how readers themselves experience reading for pleasure. Interviewers were asked to pick the most committed pleasure readers they knew who were willing to be interviewed and to conduct with their chosen interviewee an open-ended, exploratory, and conversational interview. As a framework, interviewers were given a list of questions but were encouraged to listen closely to what readers said, to follow up on themes introduced by the interviewees themselves, and to focus generally on aspects of the reading experience that were relevant to the particular reader. The first question was, "What's the first thing that you can remember about your reading, either that you read yourself or that was read to you?" Then interviewers moved forward chronologically to the present, using open-ended probes such as, "What did you read next?," "What do you remember about it?," and "Why did that book make such an impact?" Interviewers asked, among other questions, the following:

- Was there anything in your childhood experience that you would say fostered reading? Discouraged reading?

- What do you remember reading next? Next? After that?

- Are there types of books that you do not enjoy and would not choose?

- If you could get an author to write for you the "Perfect Book," what would it be like? What elements would it include?

- How do you feel about rereading?

- Has there ever been a book that has made a big difference in your life? [What kind of difference? How did it help?]

- What would it be like for you if for one reason or another you couldn't read?

- What would you say is the role of reading in your life?

None of these 302 readers was asked specifically about reading L.M. Montgomery or any other specific author, unless the interviewee introduced the author into the conversation. However, when encouraged to talk about reading that was important to them, almost one fifth of the female readers spontaneously mentioned one or 
more works by Montgomery. As was the case with Warnqvist's readers, the Canadian readers typically first encountered Montgomery when they were growing up, and a great many reported reading and rereading favourite Montgomery books throughout adulthood.

In addition to these general interviews with avid readers, Ross conducted more focused, open-ended interviews with five self-reported Montgomery fans specifically in order to collect data for her L.M. Montgomery and Reading conference talk. These five interviewees were chosen because they had read (and reread) Montgomery. They were asked the following questions, together with follow-up probes:

- How would you describe yourself as a reader?

- What was your introduction to LMM books? What did you read first, next, next, etc? [Probes: Books as gifts; shared reading]

- If you could take only two or three LMM books to a desert island, what would they be? [Probes: What was special about that book?]

- Do you reread LMM? [Probes: Under what conditions would you choose to reread? Which books? What is the value of the rereading experience for you?]

- Has reading LMM made a difference in your life? How?

Anonymity was promised to all the interviewees in both sets of interviews, and, therefore, code names are used in quoted excerpts from the transcribed interviews.

Back to top

\section{Something About the Readers}

With few exceptions, the readers in both the Canadian and the Swedish study who self-identified as Montgomery readers were girls and women and well educated, many having graduate degrees in fields associated with reading and writing. Most had read their first Montgomery book in their youth, usually between ages nine and fourteen, although some had first encountered Montgomery as an adult. Many reported reading and rereading Montgomery books over a lifetime, sometimes returning to a favourite book during the same season every year or during a critical life event, such as when writing exams, undergoing stressful medical treatment, or right after a child was born. Most readers fell within the age range of thirty-five to seventy-five at the time they submitted reading accounts or the interviews were conducted, with a somewhat wider age range in the Swedish study than in the 
Canadian study. (See above.)

The participants in our two studies were definitely not a random, representative sample of the population at large. When large national surveys in Canada and the US ask, "Have you read a book for pleasure, in part or in whole, during the past six months?" typically only fifty to sixty per cent answer "Yes," with some fifteen to twenty per cent of the population falling into the category of "frequent readers." 15 In Sweden, about seventy per cent of the population claim to have read books during an average month, thirty-six per cent on an average day. 16 The readers in our study, by contrast, were all people for whom reading played an important role in their lives-that is why they self-selected to answer a solicitation for readers of Montgomery or were chosen to be interviewed. In a nutshell, the readers who participated in our two studies were at the high end of reading engagement. These readers are important because they disproportionately buy books, borrow books, give books as gifts, read books, collect books, talk about books, join book clubs, and keep friends and family members within the community of readers. Because of the way we chose the participants of our two studies, we cannot make claims about Canadian and Swedish readers in general. Instead, we have analyzed the many stories, voluntarily told to us by Montgomery readers, and we share some common patterns and themes that emerge.

The different collection methods for the Canadian and Swedish accounts have produced some differences in the types of inferences that we have been able to draw from each data set. The subset of the 302 Canadian interviewees who described Montgomery reading as important discussed that reading in the context of their larger engagement with pleasure reading. Therefore, from the Canadian data, we have been able to tease out ways in which the Montgomery readers resemble each other and differ from other pleasure readers, and we describe some of this variation below. By contrast, because all of the Swedish readers responding to the solicitation were asked to discuss their Montgomery reading, the Swedish material allows for a close and intense examination of patterns of reading Montgomery but does not situate that reading within the context of readers' reading as a whole. In the overview of our readers that follows, we start with a big-picture look at Montgomery reading within the context of pleasure reading in general. Then, we narrow the focus and describe patterns of engagement of Montgomery readers, with an introduction to some key themes found in the Swedish data related to reading Montgomery. 


\section{Some Dimensions of Variation Among Canadian Pleasure Readers}

What did Ross find out from the 302 avid Canadian readers about pleasure reading in general? In short, pleasure readers vary greatly along a number of dimensions: 17

- Some readers look for "safe" books. Many readers said there are times they want a book that can be counted on not to give them any nasty surprises. On the other hand, horror fans seek out books that provide the intense effects of fear and menace-the more unsafe the better. Avid readers of horror describe a successful book as "one that can scare me," although they acknowledge that hardly any are scary enough.

- Some reread books, whereas others say that there are so many new, unread books out there that they cannot afford the time to reread.

- Some are voracious readers who have many books on the go at the same time. They describe themselves as omnivores who read everything at all levels of literary prestige and difficulty, from genre books to classics and demanding literary fiction, sometimes simultaneously. Others, by contrast, are very selective readers who read only "important books." These discriminating readers may dedicate themselves for an entire summer to reading, say, nothing but Roberto Bolaño's 2666 or David Foster Wallace's Infinite Jest. They are apt to say that the real question is not whether challenging books are worth the time spent but whether unchallenging books are worth the time wasted reading them. 18

- Some read mostly fiction for pleasure, while others say they never read fiction because they want to read only about "real things."

- Some want to read about characters in circumstances that are recognizable and resemble their own. Others want to read about lives they have never lived and experiences that are quite unlike their own.

Perhaps not surprisingly, the Montgomery readers in the Canadian study turned out to have much in common with each other-and at the same time to differ from clusters of non-Montgomery readers, who described very different patterns of choosing and experiencing books for leisure reading. First, on the five dimensions just described, Montgomery readers say they deliberately seek out "safe books," 
especially during stressful times in their lives. Second, they definitely reread-some say that they have read The Blue Castle ten times or that they read the entire Anne series from beginning to end and then start over. Third and fourth, Montgomery readers tend to be voracious omnivores, who read everything but especially value fiction for the way it can convey embodied truths. These readers reject as snobbish and hierarchical the idea that people should limit themselves to classics and canonical books and say that they themselves read "anything and everything," but only books they love. To those who say life is too short to read "unimportant books," omnivores retort that life is too short to read books you are not enjoying.19 And, fifth, Montgomery readers enjoy the way the worlds of Anne and Emily are recognizable, but also magicked to be more intense and special than the readers' everyday world. Most importantly, Montgomery fans tend not to like books that try to distance them from the central characters. What they enjoy is the sense that the stories about Anne or Emily and the rest are really "secretly about me." 


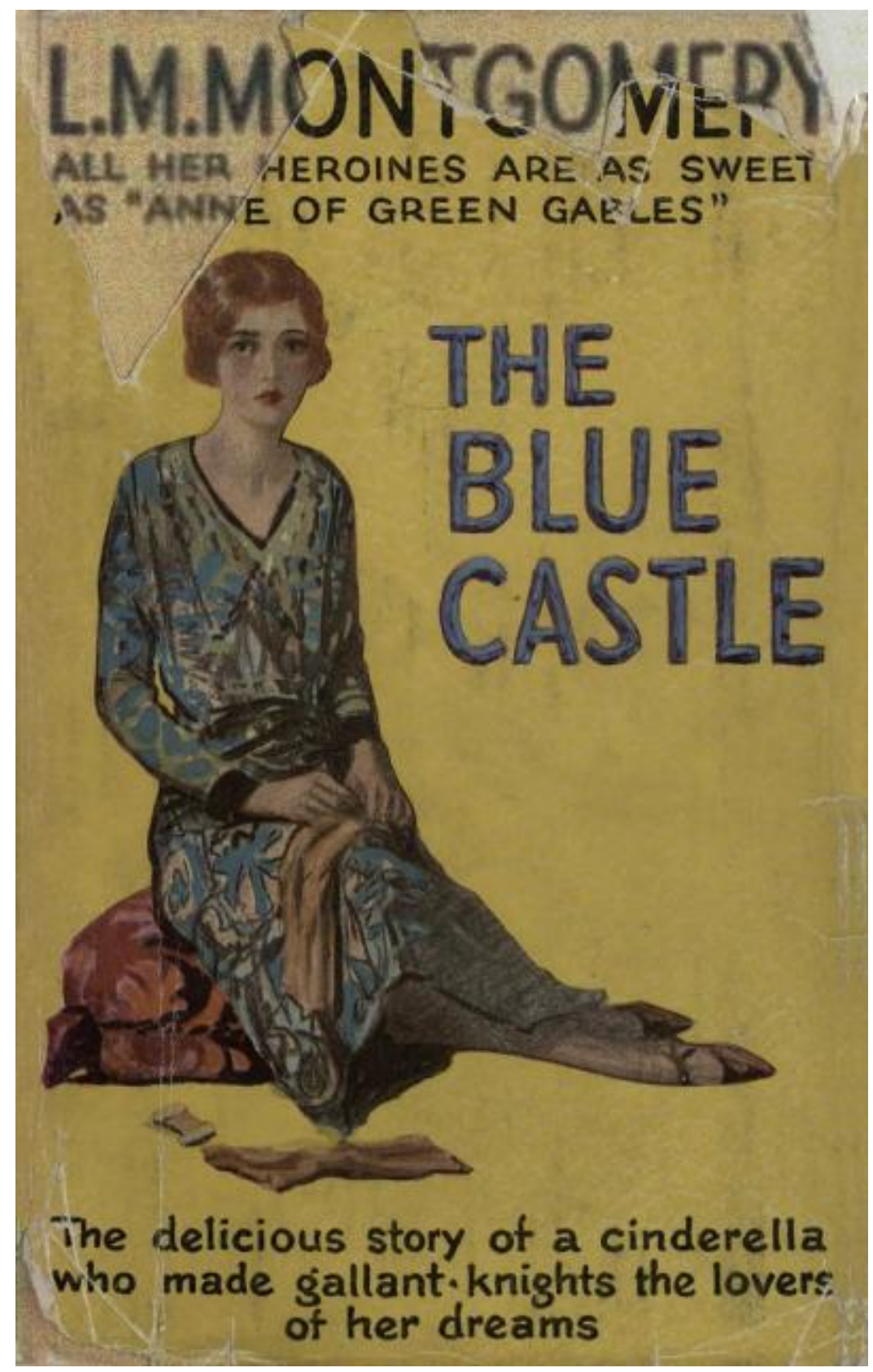

Book cover of The Blue Castle. 1926. KindredSpaces.ca, 849 BC-HSYJ.

Back to top

\section{Patterns of Montgomery Reading: The Swedish Readers}

As noted, the Swedish readers were invited to focus on their experience with Anne of Green Gables and with Montgomery generally, not to comment upon their leisure 
reading as a whole. In this section, we provide an overview of some overarching patterns and themes related to reading Montgomery in Sweden. Despite differences in emphasis in the readers' accounts, certain themes turned up again and again in the Swedish written submissions (and also, as it turned out, in the Canadian interview material).

The Swedish readers wrote about how the Montgomery books had touched and influenced them-how meeting Anne Shirley and her world was an experience out of the ordinary. In the book series, the long span of Anne's life from childhood, education, development as a teacher, marriage, and motherhood has allowed a diversity of readers-young and old, men and women-to connect episodes in the book series with significant elements in their own lives. When Anne of Green Gables was first published in the US in 1908, it was not specifically marketed to a young audience. Prime ministers and renowned writers as well as young girls and boys all read and enjoyed it.20 By contrast, when Anne of Green Gables was published in Sweden for the first time in 1909, the book was marketed as a novel aimed at young adults. Ever since, it has repeatedly been described on book covers and in reviews as a young adult novel or girls' story. 21 But, although it is true that most Swedish readers first meet Anne at a young age, the book continues to be popular among readers of all ages. The Kevin Sullivan TV adaptation in the mid-1980s served to introduce Anne to a wider audience. Broadcast on Swedish television on several occasions, the TV series expanded the book's popularity and recruited new fans of Anne in Sweden as it did in Canada.

Not surprisingly, given the initial Swedish call for submissions, many readers described Anne of Green Gables as their favourite book and Montgomery as their favourite author. Many readers had a clear memory of the first time they read Anne of Green Gables. Meeting Anne was a profound experience, vividly remembered decades later. As often happens when it comes to important occasions in life, the readers could recall when and where they were at the time and what they felt and experienced-even such everyday sensations as the feeling of a floor draft. In these Swedish accounts, readers noticed and drew attention to different aspects both of Anne herself and of the stories as narrative. For example, one reader would emphasize the humour, another the story of courtship and marriage, a third the vivid depictions of nature, and a fourth Anne's ambitions. Readers praised Montgomery's depictions of the natural landscape, admired her spot-on character portrayals, and recalled memorable expressions they had adopted for their own 
conversational use, such as being "in the depths of despair" or finding a "kindred spirit." Many described rereading Montgomery's novels, some every year and some as many as twenty or thirty times over a lifetime. Readers reported they notice new things every time they reread the books, identifying with different characters depending on their own age at the time of reading.

Readers commented in particular on the deep impression made by Anne herself. A picture emerges of Anne as a character who invites readers to make intensely felt connections between the fictional world of Anne and their own everyday lives. Readers reported strong emotions inspired by each rereading. Emphasizing how vividly Anne is portrayed, readers described how they were able to immerse themselves emotionally in the stories, thanks to the universality of Anne's experiences. They valued Montgomery's refusal to shy away from difficult topics, including death itself. For instance, when Anne's baby, Joy, dies at birth in Anne's House of Dreams, readers who had undergone a similar loss described what a comfort it was to read about it. Readers considered Anne to be a friend, but they also said that reading Montgomery had brought them closer to their own real-life friends. 


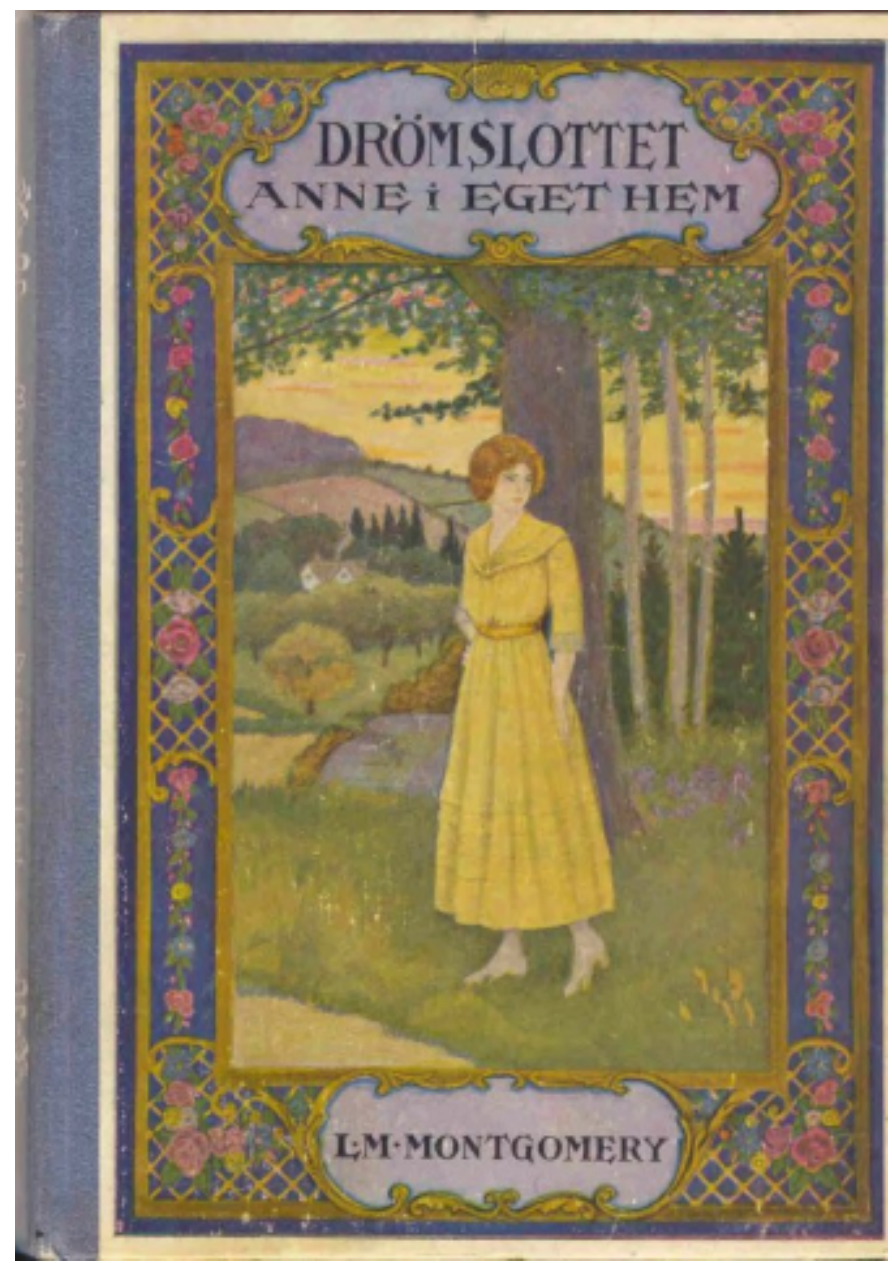

Book cover of Drömslottet: Anne i eget hem. 1918. Swedish translation. KindredSpaces.ca, 840 AHO-Swedish.

Anne was a role model, readers said, when they were making life-changing decisions, such as the choice of profession. Particularly for readers born from the 1940 s to the 1960s, Anne's example showed that the road to higher education could be open to everyone, irrespective of gender.22 The letters from Swedish readers also included many examples of readers who had been so touched by Montgomery's work that they had named their daughters Anne or Emily. Some had themselves been named Anne or Emily by their own mothers.23 The material even includes a Gilbert.

The Swedish readers also reported experiences with Montgomery books that extended beyond the literary work itself. In particular, readers described the importance of the books themselves as physical objects, with Anne books passing from generation to generation and eventually becoming family treasures. Copies 
were kept despite burn marks and threadbare spines. Bookbinders were commissioned to rebind older family members' tattered copies. In short, the work meant so much to many families that the utmost was done to keep the copies as intact as possible, ready to be cherished by new generations. In this way, Anne of Green Gables, thanks to its long publishing history, became a bridge between generations and a link between daughters, mothers, and grandmothers. 24

Back to top

\section{Emergent Themes on Reading Montgomery}

We examined the statements provided by Canadian and Swedish readers, and, after a back-and-forth process of comparison, winnowing out, addition, and refinement, we ended up with a set of ten key themes. In the sections below, we illustrate each theme with quoted statements from Canadian or Swedish readers or both. For any particular theme, many examples occur in our data sets, ranging from very brief statements to elaborated narratives. In choosing our illustrative quotations, we have picked those cases that provide the most detailed and contextualized versions of the theme, irrespective of whether the reader was Canadian or Swedish. We found a strong similarity in the responses between the two groups of readers, even in their expressions of very personal insights. This finding is strengthened by the triangulation, or convergence, in our data provided by the two different methods of data collection used to elicit reader statements in the two studies. This convergence is apparent, despite the different marketing targets (readers of all ages in North America, young adults in Sweden) and changes and abridgements done to the translation to accommodate a younger audience.25 One general observation is that Swedish readers typically mention fewer titles than the Canadian readers, as only fourteen of Montgomery's books have been translated into Swedish: the Anne books (translated in 1909 to 1985), the Emily books (translated in 1955 to 1985), Kilmeny of the Orchard (published in English in 1910, translated in 1932), Jane of Lantern Hill (published in English in 1937, translated in 1984-1985), and Chronicles of Avonlea (published in English in 1912, translated in 1968).

In the following sections, for each of the ten central themes that emerged from our analysis, we provide quoted statements from our readers as the basis for drawing out implications for understanding the reading experience of committed Montgomery readers: 
1. The inaugural book

2. The series effect

3. Rereading

4. Link between generations

5. Being shaped by childhood reading

6. "I wanted to be Anne"

7. "L.M. Montgomery brought us up": The Anne effect

8. "L.M. Montgomery trained me in romance"

9. A sense of place

10. Nature with a capital $\mathrm{N}$

Notably, several quotations used in the analysis support more than one theme, but we use each passage only once, where we consider it most apt, with cross references provided linking the passage to other relevant themes.

\section{1) The Inaugural Book}

Avid Montgomery readers in both the Canadian and Swedish studies typically have stories to tell about their introduction to L.M. Montgomery: which title they read first (usually Anne of Green Gables); whether their first experience was with a book or a filmed adaptation; who introduced them to the inaugural book (for example, grand parent, parent, other family member, friend, teacher, librarian); what made the book special enough to be remembered so many years later; and often the impact that reading Montgomery's novels had on their life.

Here is Gillian, a Canadian reader who described Anne of Green Gables as "a landmark in my childhood reading." As Gillian told the story, she was nine years old and a Brownie (the junior level in the Girl Guide movement). To win her Brownie reader's badge, she had to read a book chosen from a "pretty long list of books" provided by Brown Owl, the Brownie leader. Gillian picked Anne of Green Gables because it was the first book on the list-it started with $A$.

When I got it-I borrowed it from the library-I discovered that it was a thick book. And furthermore it had small print and not much white space and many, many chapters. So at first I was really, really intimidated by that book because: how on earth was I going to read this? Maybe I would never get my reader's badge, even though I loved reading. I kept thinking about how hard it was going to be to read this book. But it became less hard, because Anne is such a wonderful child. And it was an 
orphan story, and orphan stories were a particular favorite of mine. I got caught up in the life. ... It was the story itself that took me along. You get to live with Anne. You get to live inside her head. ... And the materiality of the book at the time, I see now as an adult, was also really important to me. It was substantial. I remember thinking: "Well, I did it! I did it! I finished this book! And I got my reader's badge!" ... The book was so big and thick that by the end I actually had had a lot of practice with that level of writing. It was part of that sense of accomplishment. (Professor of Library and Information Science, age 64) $\underline{26}$

Similarly, a Swedish reader, Linda, highlighted her own sense of pride and accomplishment in describing her first encounter with Montgomery. She was in third grade when her teacher, Miss Gunbritt, noticed she was bored by the class texts and called her into the staff room during recess:

"Have you heard of Anne of Green Gables?" she asked, picking up a thick book. Of course I hadn't. ...

Miss Gunbritt wanted me to give that heavy book a try. She said she was sure I would enjoy it. The book was her own copy and I was bursting with pride, I felt selected. ... Imagine the teacher had so much faith in me!

At home I started reading straight after dinner. And I read and read and read. And not just read: the book devoured me in a way the books about girls like Katitzi, Miranda, Nancy Drew, and Kulla-Gulla never had. [All but Nancy Drew are famous Swedish children's book protagonists.] It had a completely different approach and it literally flung me all the way to Prince Edward Island.

I, as a small gap-toothed girl with red hair, had always dreamed of long, curly, blonde princess hair. Freckles were hardly a desirable attribute for a princess, and though I found Pippi Longstocking crazy and funny, she was hardly a realistic role model for a tiny carrot like myself. Anne, "Anne with an E," was a different matter. She became my very first role model. Not just because of the hair, it was more of a common denominator reminding me that we were kindred spirits of the same disposition. No, I remember suddenly being prouder than ever of the fact that I read so much. Because so did my heroine. (Linda Karlsson Eldh, born in 1980, translator/freelance writer)

Another Swedish reader, Karin, was in the fourth or fifth grade in a small village school in northern Sweden in the early 1950s when she first met Anne. As with 
Gillian and Linda, the introduction came about not through a family member but through a teacher. While the boys were being taught woodworking, the girls were given weekly lessons in needlework, "crocheting pot-holders, cross-stitching or knitting socks." Their sewing practice sometimes was enlivened when the needlework teacher read them a story:

One day she had brought a rather thick book with a girl with red hair on the cover, and she began to read to her very attentive audience about Anne, Matthew, and Marilla in the village Avonlea-pronounced with a Swedish accent, of course.

What an experience! I sat there as though struck by lightning, forgetting all about my pot-holder, completely immersed in the story of Anne. ...

That year I wished for-and got-the book Anne of Green Gables for Christmas and later I got all the other books about Anne, too. I read-and re-read-the stories about Anne, even as an adult.

I believe it was the books about Anne that sparked my interest in reading. I never made much progress with either crocheting or knitting-but I will never forget my needlework teacher who, through Anne, opened the door to literature for me! (Karin Silverhult, born in 1943, retired teacher in English and German)

Many readers say that in childhood a particular landmark book marked the transition from one kind of reading to another. "That was the first chapter book I read on my own," they might say, or "This was the first book that made me understand that through reading I could be transported to other amazing worlds." It is notable that these three readers described their landmark book, Anne of Green Gables, in strikingly similar terms as "big and thick ... with small print," as a "thick book," a "heavy book," "a rather thick book" -in short, a challenge to novice readers. All three of these quoted readers recognized in Anne of Green Gables something qualitatively different from any other book they had ever experienced. Gillian sensed that it was "a much more serious book" than other books, such as the Enid Blyton adventure stories. Linda recalled that the Anne book "devoured" her in manner unmatched by other books she had read with young female protagonists.

For these readers, the experience of encountering this landmark book was described as a combination of elements that together explained its impact: the challenge posed by the "thick book"; the sense of pride and achievement in reading this substantial book; the breakthrough in one's identity as a reader as one moves to a 
new level of reading and accepts the invitation to go through "the door to literature"; the association of the desire to "read and read and read" with the compellingly immersive nature of story; the recognition that reading Anne was a rite of passage into becoming a reader; and the sense that this identity as a reader was reinforced by the book's representation of Anne herself as an avid reader. Gillian makes some of these links explicit: "So it was such a significant book, first because it was a major accomplishment to get through it but then there was the growing understanding that this was a really good story." By the end, Gillian's identity as a real reader was confirmed-with a reader's badge and with her own strong response to the compelling power of story. She had joined the club of people who know themselves to be readers. Similarly, in characterizing Anne as her "very first role model," Linda was "suddenly ... prouder than ever of the fact that I read so much" because, she said, "so did my heroine."

These readers' first encounters with Anne are particularly good examples of the use of literature for its immersive qualities. What Felski calls enchantment is found explicitly expressed in the quotations from Gillian, Linda, and Karin.27 Gillian describes how she got "caught up" as the story itself "took" her. Linda uses the bodily metaphors of being "devoured" and "flung ... all the way to Prince Edward Island" to characterize the dramatic effect on her of reading Anne, contrasting this reading with the more humdrum reading of other books. Karin describes feeling "struck by lightning, forgetting all about [her] pot-holder, completely immersed in the story of Anne."

\section{2) The Series Effect}

An unmistakable theme repeated by both Canadian and Swedish readers is the drive to read all the books in the Anne series, or all the Emily books, or all Montgomery books translated into Swedish.28 A commonly stated element in both sets of data was the readers' sense of excited anticipation when they discovered there were more books. Here is a Canadian reader, Renée, who was in grade three when she first read Anne of Green Gables. She said that that book "sort of started [me] off."

Renée described how she would ask for, and get, books as Christmas gifts. She said, "I used to get 9 or 10 books for Christmas, so I used to spend all Christmas day sitting in this corner reading all these books ... I read all the Anne books, Emily of New Moon, Pat of Silver Bush, and all the individual ones. It was just about two years ago I finally found $A$ Tangled Web." 
R: Have you ever read A Tangled Web? $\underline{29}$

I: No, I haven't, but I have it.

R: And you haven't read it?! Oh my God! I looked for that book for twenty years, literally-and you had it and you haven't read it! Well the sad thing is I looked for it, you know, because it's always listed on the back [of Montgomery's other books]. I looked for it for years and years and years. And one time, I was in a restaurant when I was in university, on a date. And, Holy God, there was A Tangled Web! So I grabbed the thing down and I just sat there reading as much as I could. Really I should have got up and offered to buy it from them. It took me another ten years before I found one. But yes, I've read just about all of them-My favorite one was The Blue Castle. Have you ever read that most fabulous one? It's just been my favorite book my whole life. (Physician, age 32)

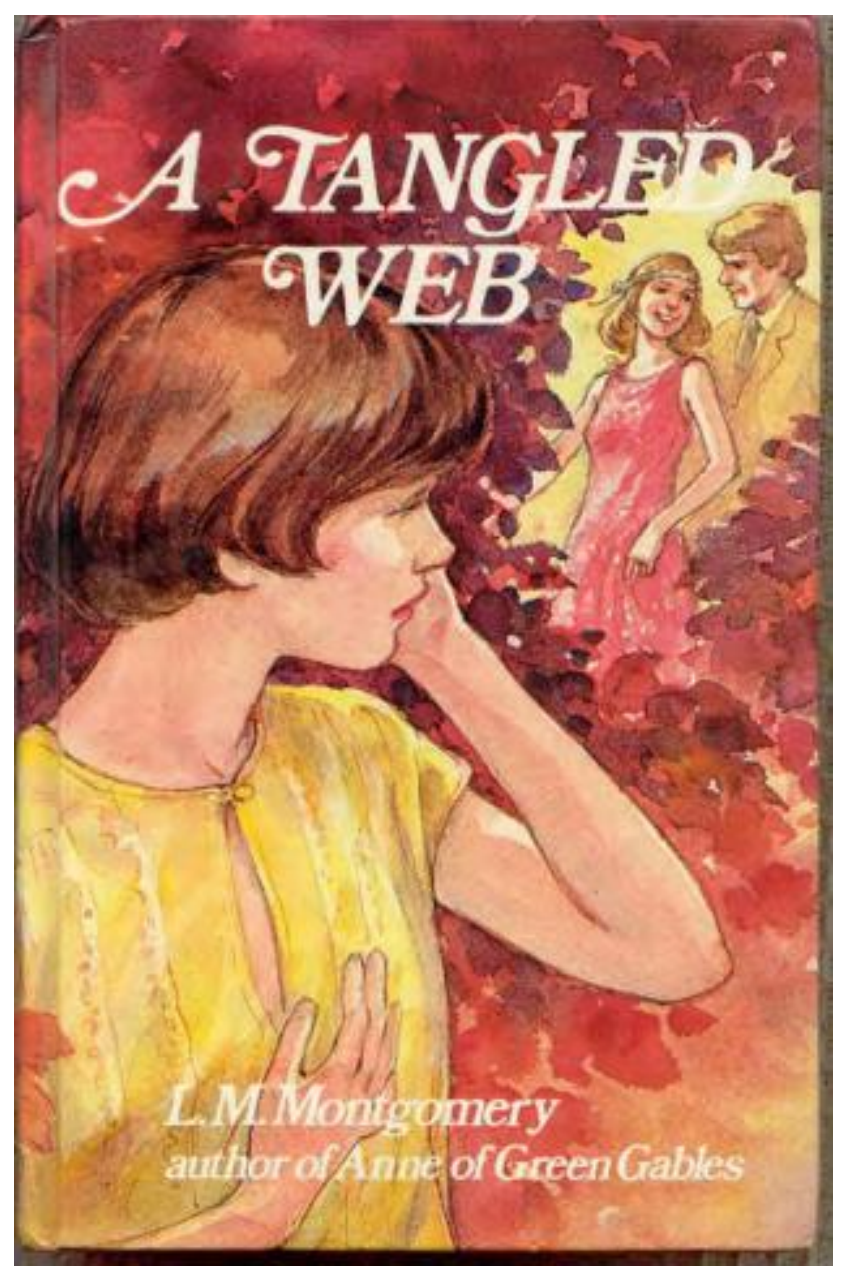

Book cover of A Tangled Web. 1982. KindredSpaces.ca, 019 TW-AR. 
For readers, and especially beginning readers, it can be hard to pick out an enjoyable book, but struggling through an inappropriate choice has the unfortunate effect of discouraging pleasure reading in general. Series books solve the problem of choice, reducing the risk involved. The series effect is important and often commented on by both Canadian and Swedish readers. Karin and Gillian (introduced in theme one) are two of these readers. When Karin wished for and received all the Anne books, they "opened the door to literature" for her. Gillian said that the discovery there were more stories "set me up for some satisfying and substantial reading for the next three or four years, until I was 12 or 13." Reading another book in a familiar series reduces the cost of getting into a new book: the reader is already familiar with the central characters and with the fictional world of the book. 30 That is why the long list of Montgomery books included in each book reassures readers that they can experience that pleasure again-they can re-enter the Montgomery world, by reading the next book. In Renée's case, there was also the drive to completion: to track down and read every last book. This is a common trait in the reader responses, irrespective of nationality. Many readers become collectors, commenting on the joy of receiving Montgomery books as gifts or finding them in second-hand bookstores.

Warnqvist has analyzed the emotional relevance of rereading and collecting Montgomery books through the lens of productive memory. She concludes that it functions as a way of productively bringing memory forward in order to engage in reinvention and gain new and deeper understandings of ourselves. 31

\section{3) Rereading}

For both children and adults, the knowledge that the experience can be repeated is a big part of the pleasure of reading Montgomery. Among the interviewed Canadian readers, about sixty per cent of them said that as children they repeatedly read and reread series books, such as Nancy Drew or The Babysitters Club or Fear Street . They gobbled up five or ten or fifteen books in the series until suddenly they stopped, having discovered that the books were "all the same." As readers, they had moved on. But many Montgomery fans continue to read Montgomery books throughout their lives. They do not leave Anne, Emily, or the others behind. Why? Readers say they reread Montgomery because the books remain unchanged-“old friends" or "old reliables" that you can count on. And, paradoxically, the books are also described as different-every time you reread them, you see something 
different that you had not noticed before. The books have the winning mix of the familiar and the new that keeps readers rereading. Here is an explanation from Evelyn, whose reading is featured in theme four on reading Montgomery as a link between generations:

To read a book from the perspective of a child is one thing, but to read it as an adult can be something quite different and it inevitably is. When I reread Anne as an adult in my late 20s, I was so much more sympathetic to Marilla. Who isn't? The book was almost as much about her, I realize now-about her change and the awakening in her life-as it was about Anne. You have a much more compassionate perspective on the older characters in those books now than when you were 10 or 11 , when you would only see from the perspective of a child. (Retired professor of English, age 64)

Montgomery books have layers and depths that support rereading. So many characters of differing ages are depicted, including Anne and Emily themselves presented at different ages, and so many milestones of life are represented, that readers find it easy to read themselves into the text. A reread book, our informants say, is a different book because different characters and situations move to the foreground to resonate with the reader's own life experiences. 32 They read their lives into Montgomery's stories, and they read the stories back into their own lives.

Swedish reader Maj described how the books changed for her, following her own progression, as she read over a lifetime the editions published in 1920 that had originally belonged to her mother:

Anne has followed me through life, from the age of ten. My mother, born in 1912, had the books and these editions were published in 1920. Now they're on my bookshelf, tattered and kept in plastic bags so as to not fall to pieces entirely. Last time, but surely not the last time, I read them all was in 2006.

I'm about to turn 71 and I have kept rereading them, maybe every seventh or eighth year. During my time as a child, teenager, adult, and now an elderly person the books have followed my progression, and they have seemed new to me every time.

I'm not a very sentimental person, but, Good God, the tears I've cried while reading these books over the years! When Anne lost her little daughter I was a teenager, but when the same thing happened to me at the age of 22 it was a few years before I could re-read it. (Maj Larsson, born in 1937, retired) 
Canadian reader Scarlett explained that when she rereads Montgomery, it is not just the book at two different times of reading - that is, two different versions of the book-but two different versions of herself doing the reading.

R: When I was 12 or 13 , I read The Blue Castle six times in a row. I'd get to the back of the book and go right to the front again. I just read it constantly. I was growing up in a really evangelical Christian family. Valancy's struggle with her family speaks to a coming-of-age-breaking free of the parents and finding your own independence. Actually my parents' marriage was ending that year, which is an interesting light to think about it in. So that might have fed into it a bit too. ...

\section{I: Typically when might you decide to reread an LMM book?}

R: When I'm trying to connect the narrative of my life and make sense of my present-putting on those shoes-because I can feel again like I felt when I was young. And then you can connect with that inner child or teenage version of yourself or different periods in your life when you were reading the books. There's a selfsearching part of it. ... It's not just seeing the book as you saw it as a child versus how you see it as an adult. It's seeing yourself as a child and yourself as an adult. And that contrast. It has a therapeutic function, really. (Bookstore owner, age 41)

These statements from readers demonstrate that, in addition to offering guaranteed pleasure, rereading Montgomery can have a therapeutic function for readers wanting a safe framework within which to make sense of an intense personal experience. In her study of reading, Felski identifies and analyzes four modes of textual engagement: recognition, enchantment, knowledge, and shock. 33 Of these, recognition is the form of engagement most often mentioned by our Canadian and Swedish readers. In Felski's analysis, readers' engagement with a text offers opportunities for cognitive insights into the self, a self-understanding that comes about from recognizing oneself in a book, seeing something new in oneself and thereby understanding oneself in new and different ways.34 Consider the many readers below who describe how Anne provided a model for identity that helped them make important decisions. (See also themes five and six, below.) As Scarlett puts it, "There's a self-searching part of it." And in addition to self-discovery, readers also find "solace and escape," as Montgomery herself did through her writing, returning to her everyday life with "renewed courage and 'grit.'” $\underline{35}$ 
From the reported reading experiences, we can infer that Montgomery's books perform these functions so well because Montgomery was able to create characters who feel things with great intensity-joy, despair, a sense of injustice, exhilaration, fear, resentment, love, rebellion, jealousy, friendship. Moreover, her books depict commonly occurring situations, such as the unwanted or unappreciated child, the lost or absent father, the death of a baby, the loss of a beloved family house, and the repressed, put-upon spinster-situations that resonate, in one way or another, with significant events in the lives of readers. In her discussion of Finnish Montgomery readers, Kannas comes to a similar conclusion about reading and rereading Montgomery, during which books become "identities, memories and parts of the self." $\underline{36}$

\section{4) Link Among Generations}

When books such as Anne of Green Gables are beloved by readers for over a hundred years, they become a bridge across generations. Reading Montgomery can be a family affair, in which the parent or grandparent, aunt or uncle explicitly initiates the child into Montgomery reading, sometimes by giving a new gift book and sometimes by passing on an old tattered copy that belonged to a mother or grandmother. Warnqvist has noted that in the accounts from Swedish readers many emphasize that two, three, or even four generations of women in the same family have read the Anne series. 37 Mothers and grandmothers share the ways in which Montgomery's novels have been important to them and also express a wish to introduce the novels to their daughters and granddaughters. Swedish and Canadian readers equally report on collections of Montgomery books, carefully preserved and lovingly handed on to a younger generation of readers.

In Evelyn's case, reading Montgomery was definitely a family affair. When she was four-and-a-half, her sister, who is three years older, taught her to read, after which Evelyn became a voracious and omnivorous reader. She described herself as a "constant reader" of Montgomery. Evelyn's mother and her aunt had read Montgomery as the books were being published. When Evelyn's aunt was ten years old, she wrote to Montgomery to say how much she enjoyed the books. Evelyn reported that Montgomery "wrote back this gracious little response, saying how pleased she was to have heard from her, how she wished her the very best."

Evelyn's mother made sure that her own two daughters had all the Montgomery books, and she read these books to them aloud as bedtime stories, well beyond the 
years when they began to be able to read for themselves. Evelyn and her sister, between them, received the full suite of Montgomery books as gifts to mark special events such as passing to the next grade in school. Then when Evelyn was eleven, she and her sister were taken to Cavendish as part of a family visit to Prince Edward Island. As adults, Evelyn and her sister split the family Montgomery collection between them. To fill in the gaps in the divided collection, her mother, described as "an inveterate searcher-out of second-hand books," sent Evelyn a lot of replacement copies, including a second-hand copy of Rainbow Valley and Kilmeny of the Orchard. Summing all this up, Ross said in the interview: "So there's a family connection. And it's not just reading. It's visiting the sites, preserving the letter, and keeping all the books from childhood." And Evelyn agreed, "It's the full fan experience. The Graceland-type experience."

Here's how Evelyn describes her childhood reading of Montgomery:

I read all the Anne books by myself. However my mother loved to read aloud to my sister and me. She would read to us every night, right up until I was 10 or 11 and my sister was 13 or 14. I got caught out, inadvertently revealing that I had read ahead of the book, which was Pat of Silver Bush. My mother said, "You read ahead!" [Laughter.] I must have read Anne of Green Gables by now perhaps hundreds of times. I reread everything. We had all the Montgomery books. My mother had been a fan, obviously, and so was my aunt, who famously wrote to L.M. Montgomery. So we always had them all. The only one we didn't have was The Blue Castle. That was because my mother thought it not suitable-I think she read the book flap and the not-quite-lurid book jacket. I asked for it when I went from grade 5 into 6 and my mother said, "Are you sure?" I said yes; that otherwise I would have to get it from the library. She bought it for me. I still have that copy too. So we had them all prior to my age 11 . So my sister and I between us managed to cover the entire LMM canon-literally. (Retired professor of English, age 64)

As became evident in so many stories told to us by readers, leisure reading is not a solitary, isolated activity but is connected by many strands to other people in the reader's life from teachers and librarians to friends and family members. In Evelyn's case and that of so many other Canadian and Swedish Montgomery readers, these social connections include shared bedtime story-reading; giving and receiving gift books to celebrate milestones in life; creating book collections; and participating in fan behaviour such as writing a fan letter or going on a literary pilgrimage to 
Cavendish. These and other activities create a bond among readers of several generations in the same family, making them part of a female reading tradition. 38

\section{5) Being Shaped by Childhood Reading}

There is a back-and-forth movement between the reader's everyday world and the world of the book. Readers bring to their reading understandings and preoccupations from their own lives. But then they take things from their reading which shape their view of the world and of human relationships. Often readers said that reading the right book at the right time gave them an insight into their own life and helped them make a decision or resolve a problem or take a course of action. (See also theme three, above.) $\underline{39}$

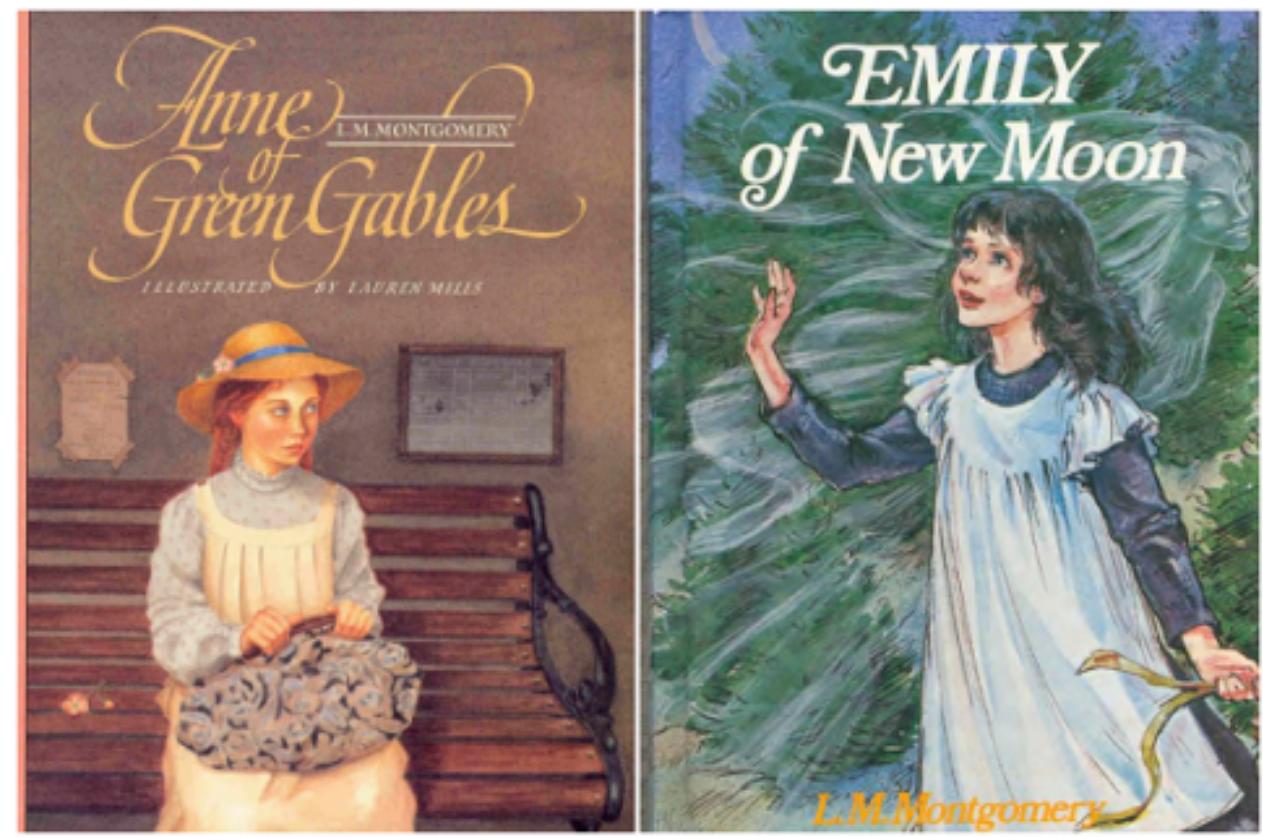

Left: Book cover of Anne of Green Gables. 1989. KindredSpaces.ca, 247 AGGGODINE.

Right: Book cover of Emily of New Moon.1982. KindredSpaces.ca, 013 ENMAR.

Accounts from both Swedish and Canadian readers include many varied ways in which reading Montgomery shaped their lives: for example, choosing teaching as a career as Anne did; deciding to be a writer like Emily; play-acting the friendship of 
Anne and Diana with their own friends; self-consciously paying attention to natural beauty in their own environment and making explicit connections with the Lake of Shining Waters or the Snow Queen or the Wind Woman (see theme ten); seeking out "kindred spirits"; and so on. One Swedish reader reported finding "orphaned, brave, and creative girls and young women of girls' fiction irresistible," and that, of all the creators of spunky female heroines, Montgomery was her favourite: "There is so much more to say, but the most important aspect of my relationship with Montgomery is that her books sparked my love for literature" (Tiina Rosenberg, born in 1958, professor of gender studies). Yoshiko Akamatsu describes how Japanese readers read Anne as a "guidebook for life" and are inspired by Anne's "imagination, [her] love for nature, and [her] desire for study." 40 Suvi Ahola and Satu Koskimies found similar patterns and concluded that the books' influence on Finnish readers was likewise profound and "much deeper than [they] ever expected." $\underline{4}$

A Canadian reader, Scarlett (see theme three), was very explicit about the way in which modelling herself on Anne gave her the courage to stand up for herself and chart her own direction in life:

I: What difference did encountering L.M. Montgomery make to your life? I know that's hard.

R: No, it's not hard at all. It completely crafted my personality. I was playing Anne. I wanted to be Anne. My best friend since I was 9 explained this to me. She said, "Scarlett, you always jump over the line. There's a line; you jump over itevery time." That comes from Anne. I've been in many situations in my life where someone told me I wasn't good enough or I couldn't do it. And I just went and did it. That comes from Anne, because I had that modeled for me. My model for feminism, intelligence, strength, outspokenness-that all comes from Anne. Absolutely directly. ... If I hadn't encountered Anne, I would be a totally different person. ... Yeah, Montgomery is absolutely a seminal part of my life. (Bookstore owner, age 41)

Swedish readers made similar statements. Eva addressed Anne directly in her reading statement when she said, “I don't think I would have been the person I am today, if it weren't for you" (Eva Lindsten Nilsson, born in 1949, Ph.D. student in psychology). Another Swedish reader, Maria, who first encountered Anne when she was thirteen, used the metaphor of "literature as a compass" to explain Anne's role in her life: 
I know she taught me to use literature as a compass in life. I also know she is very much responsible for my choosing to become a teacher. ...

Many years later I watched the TV series. Normally I'm not a particularly emotional person, but I cried and I cried. What touched me and moved me to tears must have been what I had as good as forgotten-that Anne of Green Gables influenced my choice of profession, but also the emancipatory power of the books: if orphan Anne could do it, so could I. So I became the first university student in my family despite my mother's protests, while my father with his encouragement and pride became the equivalent of Marilla and Matthew. (Maria Gunnarsson Contassot, born in 1944, project manager in teacher education at a Swedish university)

Like other avid pleasure-readers, $\underline{42}$ Montgomery readers often say that a particular book or character in a book provided a model for identity, helped them make an important decision, or strengthened their resolve. The key feature of the formative book is that it tells a story that readers connect with their own lives, often in ways that are not predictable in advance or apparent on the surface to outsiders. In describing the "emancipatory power" of books, Maria speaks for many readers, both Swedish and Canadian, who said that a literary role model gave them the courage to make a decision opposed by a family member or the strength to bear a blow in their everyday life ("if orphan Anne could do it, so could I.") This power found in the fictional character's ability to cope with a situation and survive gives readers courage and hope.43 There are additional examples in the next section of readers finding strength and resilience through their sense of connection to Anne or to other Montgomery heroines.

\section{6) “I Wanted to Be Anne"}

Now we come to the very heart of the matter: the intimacy of the connection readers feel to a Montgomery character. Both Canadian and Swedish readers reported various efforts to become that character, to be as close to her as possible. Not every Montgomery reader wanted to be Anne, of course. Some preferred Emily or, in the case of the Canadian readers, Jane or Valancy. For example, Swedish reader Anna Remmets (born in 1985, student) said that, for the ten-year-old girl she was then "who spent all her time telling stories," Emily was preferred because "she wasn't as happy and bubbly as Anne. Her quiet, introverted, and sometimes sulkily proud character suited my temperament much better." 
For Malin Nauwerck, encountering the Emily books at age thirteen was transformational and provided what she called "my first literary revelation, the 'flash' the Emily books stirred in me":

[I]t suddenly dawned on me that you could devote your life to literature. There are books whose cobweb can cast a spell over your own life. It makes you rename the jasmine outside your window The White Fairy, think of yourself as "the moonbeam of a blue summer night," or skip class to spend the day describing scents and plants at Bergius Botanic Garden. It makes you rebellious, and proud, and prone to describe other people by writing "portraits" in your notebook ...

[Emily] slipped inside me, became my shadow, my companion, and my very own secret. For a long time, I thought I was the only person to have become one with a literary character. At one point I changed the spelling of my middle name from Emelie to Emily (keep in mind that Emily herself at one point changes the spelling of her name to make it sound more French ...). Emily provides the reader with tools for survival. (Malin Nauwerck, born in 1985, student and later Ph.D. in literature)

Anne was the character Canadian and Swedish readers most often singled out as special-as their "other self" and sometimes as their friend. Here's Eleonora Johansson, who described a secondary-school class activity in which students were asked what object they would save in case of fire. Classmates answered "my photo album," "a necklace my grandma gave me," or "my video game," but Eleonora said "a book, Anne of Green Gables by L.M. Montgomery," to the surprise of her teacher:

What [the teacher] failed to understand was that the moment I was introduced to Anne, many years earlier, I fell head over heels for her. I embraced her and her story as my best friend, and she has followed me through life ever since. The book, a joint edition of Anne of Green Gables and Anne of Avonlea, is still sitting on my bookshelf, as an eternal link to one of the best reading experiences of my life....

In hindsight, as an adult, I can see that as a girl, I partly identified with Anne. In a world that wasn't always safe, I could relate to her longing to have a home and to belong somewhere. I was relieved she wasn't pretty in a standard sense; it made her more realistic. I admired her courage to march to the beat of her own drum, never letting those around her limit her wishes and dreams. I was enchanted by the beautiful landscape, entertained by her shenanigans, and amazed by her courage to stand up for herself in different situations, even if it took hitting the most popular 
boy in the class over the head with a slate.

I felt the need to get as close to Anne as possible, and read the stories over and over. I bought hair dye at the store to make my hair as red as possible ... and I sewed clothes for my dolls using Anne's clothes as my inspiration. I saw similarities between myself and Anne, and it made me feel hopeful: things had turned out well for Anne, so I would probably be fine, too. In a way, she became my Mållgan [a make-believe friend in a famous Swedish children's book], my make-believe friend whom no one else knew about and who let me be myself. In hindsight, I can see that Anne and the stories about her inspired me to find my own path in life, and gave me the strength to keep on following it. (Eleonora Johansson, born in 1979, prosecutor)

Another Swedish reader, Margareta Swerre, reported that when she was a twelveyear-old on holiday with her family in the small Swedish town Osby, her mother said that she could pick out a book to buy. In the bookshop, she was looking at the Jill series books when her mother saw Anne of Green Gables and said, "We'll take it." Upset that she hadn't been allowed to pick out a book herself, Margareta started reading somewhat reluctantly at first. But then:

I think it was the first time I "devoured" a book. I met someone who was like me! I found a language that didn't exist in my family, but in me. I found someone who had a raging sea of emotions within, just like me, and who managed to get into all sorts of trouble, just like me. Suddenly there was a world I could understand and participate in with all my being. I think it gave me a key to my own, inner world during the challenges of preadolescence. It gave me a dream world to visit that mirrored reality with love, even in terms of hardship and failure. In Anne of Green Gables, there is room for every emotion a person could go through and relate to. It also conveys a sense of faith in that things will be fine in the end, even if it doesn't always seem that way at first. ...

Now, at the time of writing, I realize what a great influence the Anne books have been in my life. I made a similar choice of profession to Anne's when I trained to be a preschool teacher. And for the past 17 years, my family and I have provided a foster home for children and adolescents from broken families. Perhaps, in my work with children, I have been unconsciously inspired by how Anne, feeling unloved, came to a home where she was accepted and loved, and how it changed her circumstances and whole life. (Margareta Swerre, born in 1951, employment officer) 
And finally, there's Inga Mörkberg, who said she is "absolutely convinced that a certain book can be crucial, heartening at a particular stage in a person's life." So it was for her, "sitting with her back against the tile stove reading Anne of Green Gables" during a Swedish winter in the 1940s when she was twelve. She would sometimes read it "three times in a row" and "knew the chapter titles by heart."

Like Anne, I am a foster child, and perhaps not the foster child the parents had hoped for. Maybe Marilla Cuthbert's disappointment in Anne for not being a boy is as great as Aunt l's disappointment in me for not being the girl she expects me to be.

The tile stove is warm against my back, the draft from the floor is freezing cold against my thigh and leg. In that moment, I am Anne, and Anne is me. She has red hair and green eyes, I have black hair and brown eyes. Why get hung up on such details?

When Aunt I scolds me for daydreaming, for being clumsy when it comes to anything practical, for reading too much, she is Marilla, and I am Anne. ... My best friend is Diana Barry. And so, they became one-my world and Anne's. (Inga Mörkberg, born in 1932, retired special education teacher)

Female readers of Montgomery are apt to say that these books are "secretly about me." One Canadian reader said, "I felt that L.M. Montgomery had written those books precisely for me. That she had me in mind." The theme, "I wanted to be Anne" (or Emily or Jane or Valancy), is at the centre of what makes a Montgomery book so popular with its fans. Being Anne also means living in Anne's world, which was described by many as a place better than our everyday world. (See theme eight.) 


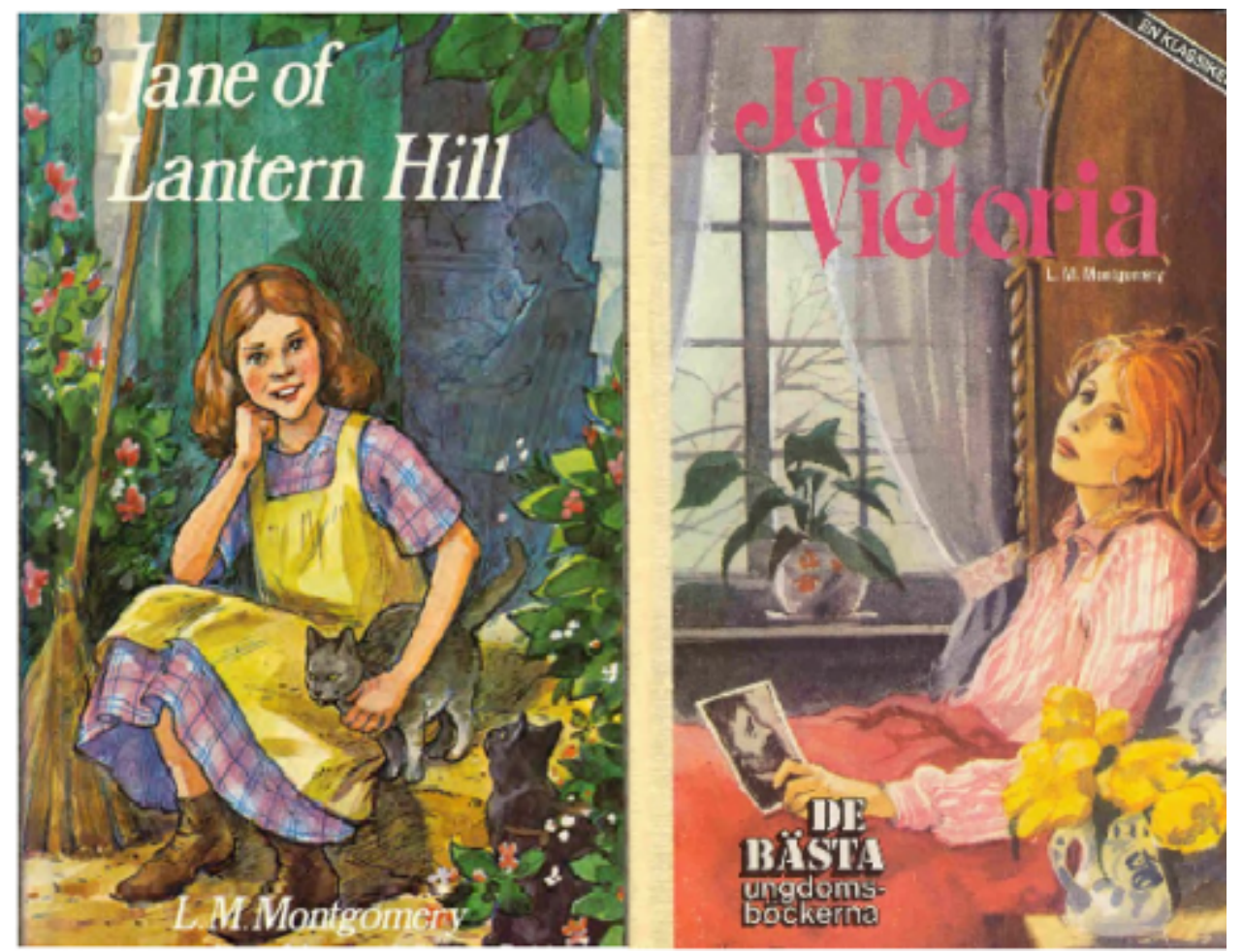

Left: Book cover of Jane of Lantern Hill. 1980. KindredSpaces.ca, 022 JLHAR.

Right: Book cover of Jane Victoria. 1984. Swedish translation. KindredSpaces.ca, 329A JLH-Swedish.

As the quotations from readers demonstrate, this theme of identifying with Anne is closely linked to other themes discussed in this article: rereading; the book as a gift from older female relatives; preserving the physical book as a link to a vivid reading experience in the past; making life choices and pursuing activities that are modelled on those of Montgomery characters; reading Montgomery for its therapeutic effect; and so on. Notably the readers quoted in this section use similar images and metaphors to capture the sense of intimacy they yearn for: "slipped inside me, became my shadow, my companion, and my very own secret"; "become one with a literary character"; "the need to get as close to Anne as possible"; "someone who was like me ... just like me"; "a key to my own, inner world"; "gave me a dream world to visit that mirrored reality with love"; "they became one-my world and Anne's." Going well beyond the claim that a particular character became a role model for making a choice or a decision, these readers seek identity and oneness. They report wanting to be like Anne because they admire her spunk, her imagination, her loving nature, and her goodness. (See theme seven.) 
But there is another aspect to this desire for closeness. Because there is "a little bit of orphan in each of us," as Joseph Gold remarks in Read for Your Life, 44 reading Anne offers hope that, by being Anne, the readers may share in her happy ending. Eleonora said, "In a world that wasn't always safe, I could relate to her longing to have a home and to belong somewhere. ... [I]t made me feel hopeful: things had turned out well for Anne, so I would probably be fine, too." Margareta, who has provided a foster home for children of broken families, said she may have been "inspired by how Anne, feeling unloved, came to a home where she was accepted and loved." And Inga, a foster child herself, demonstrated how a book may be "crucial, heartening at a particular stage in a person's life" when she described how her world and Anne's world "became one."

\section{7) “L.M. Montgomery Brought Us Up”: The Anne Effect}

The decision to interview Eunice was clinched when she remarked, "My sister and I always say that L.M. Montgomery brought us up." During the interview, Eunice explained that, for her and for her sister, who is younger by two years, "the Anne books were a sentimental and moral education," which she defined as an expansion in "one's sensibility; what you notice, what you feel about people; one's capacity for empathy." Eunice described herself as the oldest daughter in a family with "a very unhappy mother, too many kids [six, one of whom died at birth], and a father who was the kindest person possible but who was feckless and who couldn't handle money." She said, "So [Avonlea] was a different world from the world of our household-a different sensibility." Here's what Eunice said in answer to the question, "What difference has reading LMM made to your life?"

R: I would say it was a sentimental and moral education. ... I think what surprised me was how you are hit-I was hit-sentimentally and morally by Anne herself, by her effect on other people. Because she always had a good effect on people. She helped people be better. She always brought about transformations in people. Here she is just gaily tripping and skipping and having peccadilloes and wreaking havoc on small levels and yet doing people good, all the way through. And I just thought, "Wow, to be that good!"

I: You thought that when you were 11 or you thought that later?

R: I think it was happening when I first read her and that's what I liked about her. But I probably didn't formulate that. I didn't say, “I'm going to read this book 
because it's going to make me sentimentally more empathetic and morally more wanting to be good." But I did grow up with that sense that I should be doing good. ... So Anne was lovable and she was loving. It was just this-and maybe you attribute it to romance as a genre-but it was the world. I longed for that world. From the moment I read it, I wanted to live in Prince Edward Island. ... I loved the world, the innocent world; the good world; the quieter and slower world. ... I wanted to have people in my life who had the Anne effect on me-people who were really good. ... I wanted to be a good person and found it very hard, with my temperament, to be good and to be kind. But I always found really good people who were like Anne-they were Annes in my life. It began with that-it was loving someone who was so good and so lovable and so loving and always made a difference to people. Anne always did them good. And also [the Anne books] were great stories, great fun stories, that you went away into. You went away into a new world and a different world that you loved to be in and with a person you loved to be with. (Retired human resources manager, age 64)

Historically children's literature has quite often been written to make children "good" - to be obedient, to be pious, to carry out their duties diligently, to be neat, and so on. But when Eunice says that Montgomery brought her up, along with her sister, and gave them both a "sentimental and moral education," she meant something different. Anne provided a moral education and training in empathy not because she was a model of decorum, but because she wasn't. Instead "Anne was lovable and she was loving," and she inspires readers in general to want to be more loving and more kind. As Eunice puts it, despite "having peccadilloes and wreaking havoc on small levels," Anne helps people be their best selves: "She always brought about transformations in people." Eunice explicitly links Anne's being both good and loving to the existence of an innocent world of romance, which is described in the next theme.

\section{8) “L.M. Montgomery Trained Me in Romance"}

The impact of reading and rereading a beloved author may go beyond the localized influences to shape a reader's entire world view. Evelyn-the reader whose aunt wrote a fan letter to Montgomery (see theme four on the link among generations)-said that being a constant reader of Montgomery "shaped the way I use language, the way I see literature." She described the L.M. Montgomery stories as the "shaping narrative of my life," introducing her to the patterns and 
conventions of romance about which she wrote in her master's and Ph.D. theses. She said, "I realize that it was my reading of L.M. Montgomery that trained me in romance. I realized later that it was L.M. Montgomery's books-all that reading and rereading. I knew all the conventions, although I wouldn't have called them that when I was a kid. I knew that narrative like the back of my hand, because I'd read it hundreds of times."

\section{I: So in a nutshell, what is that narrative?}

R: The narrative is the creation of a world which is similar to our own, but better. And the characters are recognizable going all the way back to fairy tales and all the way forward into popular movies. ... It's that world in which things are just slightly magicked from one's own real humdrum existence in Saskatoon, Saskatchewan. PEI just seemed like this magical place. You could see the beauty through Anne's eyes. This is where we all identified with Anne. We were sure that we had that magic sight. ... I believe that this is the Canadian narrative, the Canadian story. It is fundamentally to imagine a better world than the one in which we are currently dwelling. (Retired professor of English, age 64)

Different readers are attracted to stories with very specific and particular appeals, shaped and patterned in particular ways to produce particular effects in their readers. Horror fans, as noted earlier, seek out books that scare them. By contrast, Montgomery fans choose to read and reread her books because they want to live for a while in a chosen fictional world that is happier, more gracious, more loving, and more interesting than their own everyday world. When Evelyn talked about romance patterns and the creation of a fictional world better than our own, she was thinking of Northrop Frye's formulation of the world of romance in his influential book, The Secular Scripture (1976). In Frye's use of the term, romance refers to a pastoral, idealized world close to the heart's desire, where goodness is possible, nature is tamed and benevolent, and conflicts find resolution in the discovery of identity and the celebration of community.

Canadian and Swedish Montgomery readers typically don't use the word "romance" to gesture toward what they enjoy about Montgomery's fictional world. But when they describe what they like about the books, they touch upon the key elements of romance as highlighted by Frye: the centrality of the figure of the child; the presentation of a humanized landscape, often in the form of a garden in springtime; the representation of the built environment as a house, a farm, or a rural 
community; and a narrative arc in which everything works out, conflicts are resolved, and lovers are united. $\underline{45}$ Romances typically start off in a lower world of alienation, separation, and anxiety (think of orphan Anne's prospects as a drudge in the household of Mrs. Peter Blewett) and move to an idyllic upper world that is closer to the heart's desire than is our everyday world. When readers choose to read or reread Montgomery, they get to live for a while in this "magical place," whose beauty is seen through the eyes of an imaginative child. (See theme ten on nature.)

\section{9) A Sense of Place}

Some books stamp in our memories an indelible sense of place.46 Long after they have forgotten the ins and outs of the plot, readers of the Montgomery books recall the red clay roads, rolling green fields, blossoming apple trees in springtime, and blue waters of Prince Edward Island. The place that Elizabeth Waterston has called the "magic island" resonates strongly with readers, often in different ways. 47 For some Canadian children, especially those who first encountered Montgomery decades ago when the children's books they read were mostly written and set elsewhere, Montgomery's books were special because they depicted a world that was specifically Canadian and offered readers the opportunity to see themselves mirrored in fiction. And for some Canadian readers with literary ambitions, the existence of the Anne or Emily books was proof that writers could live in Canada and write stories based on their own experience, set in a recognizably Canadian setting. Canadian author Jane Urquhart ends her biography of Montgomery with the chapter "Her Reader," in which Urquhart's grandmother puts Anne into the hands of Urquhart's eleven-year-old mother, who lives in rural Ontario.48 This young reader feels "a shock of recognition" that she is reading about her own world and borrows a typewriter, declaring, "I am going to write a novel."

Here's Elizabeth, who grew up in Bathurst, New Brunswick, across the Northumberland Strait from Prince Edward Island, describing her own shock of recognition:

All the children's books I read as a child described an environment quite unlike my own, one in which children were always scurrying off onto the fells or learning to sail boats. Or, in the case of Little Women, they were going out to nurse the poor in hovels. Just everything was quite different. I never, ever assumed that the surroundings of the children in books would be anything like the surroundings that I had myself. ... The books that I read as a child that were nearest to my own 
experience were certainly L.M. Montgomery's, who after all was writing about a small community in the Maritimes, and about the experiences of children there. The children seemed to be recognizable as me and my classmates, and the experiences were recognizable as those which my grandparents would have had as children. So there was a kind of special immediacy about those books. (Ph.D. candidate in English, age 35)

Interestingly, Swedish readers also frequently mentioned feeling a sense of familiarity and recognition when they read the descriptions of the Prince Edward Island scenery in the books. Many of them felt as though the Anne books described their own backyard. Several also wrote that they were surprised when they found out that the books did not take place in Sweden. As Cornelia Rémi has pointed out, Sweden and Canada share the same kind of flora and changes of season. Moreover, the Swedish translator Karin Jensen made adaptations and supplements to adapt the novels to the contemporary socio-cultural context of the young Swedish audience. $\underline{49}$ Some Swedish readers, however, noted the strange personal names and place names which were difficult to pronounce, and some of them-although not all-sensed or understood the geographical distance. Rémi concludes that both the exotic and the familiar are present in the books, which makes them suit both readers who want to experience the exotic and readers who seek the familiar. $\underline{50}$ Irrespective of the level of recognition, Swedish readers found as good a story in the Anne books as did the Canadian readers. The reading responses support Rémi's argument and show that Montgomery's novels attract both readers who want the characters, situations, and geographical settings they read about to be familiar and those who want to experience in their reading a world perceived as foreign and quite unlike the one they know.

\section{0) Nature with a Capital $\mathbf{N}$}

Reading Montgomery has taught generations of readers how to engage with the world in a creative and imaginative way. The Swedish responses in particular often included comments on Montgomery's descriptions of the beautiful Prince Edward Island scenery, the changes of the seasons, and the protagonist Anne Shirley's sense of wonder in relation to flowers and trees. Anne has shown readers how to look upon nature with the eye of the imagination. Unimaginative people may see only the Avenue or Barry's Pond, but for Anne, as well as for the readers, it is the White Way of Delight and the Lake of Shining Waters. Here are some Swedish 
examples of the power of Montgomery books to heighten readers' responses to the natural world:

I loved all the wonderful names Anne came up with for the places she liked. It inspired me to do the same. I never told anyone about my fantasies, but I was always on the lookout for tiny hills, groves, babbling brooks, and trees to name. (Ingrid Håkansson, born in 1941, retired special education teacher)

Anne, I have stepped over the threshold into your world innumerable times. I have watched you run across the fields, your red hair flying in the wind. I have watched your grey-green eyes shine. I have loved your east gable room, run through the Haunted Woods, felt the taste of crab-apple preserve, and kissed tiny flower buds (I still do sometimes). (Eva Lindsten Nilsson, born in 1949, Ph.D. student in psychology)

Someone once taught me this: to see the wonders around me and the art of rejoicing in being able to name it. That's right, it was Anne of Green Gables! I know with absolute certainty that I got these gifts from her. ... Anne became my best friend, and greatest role model. ... I had the pleasure of walking by myself to school through a little forest, where I could enjoy a sense of wonder, and let my imagination run wild every day, inspired by Anne's inventiveness. (ÅsaLisa Linnman, born in 1949, illustrator and conservationist)

Reflections on Montgomery's nature descriptions seemed especially salient for Swedish readers, appearing in the Canadian responses less often and less effusively, and usually in the form of brief references to the Haunted Woods, Wind Woman, or Snow Queen or in descriptions of the way in which reading Anne gave them new eyes for looking upon nature. Of the 303 Swedish reading accounts, about one quarter explicitly comment on Montgomery's depictions of nature, and plenty more refer in general terms to the landscapes, environments, and place names of Prince Edward Island.

When ÅsaLisa rejoices in being able to name "the wonders" around her, one could argue that the central issue is not so much nature itself as it is Anne's creative use of language. In many passages quoted above, the readers' appreciation of Montgomery's description of nature is closely linked to Anne's practice of imaginative renaming. In her introduction to the character of Anne during the carriage ride to Green Gables, Montgomery represents Anne as an Adam figure, 
naming the world, using words such as White Way of Delight that allow others to see the natural world in a new way.

For two outstanding writers, one Canadian and one Swedish, this awakened appreciation of nature was certainly linked to language. In Alice Munro's story “Lying Under the Apple Tree" in The View from Castle Rock (2006), the narrator recounts how, at the age of thirteen, she rode her bike into the countryside so that she could lie under an apple tree and look up at an "upside-down sea of blossom." The narrator says that she did this "because I was secretly devoted to Nature. The feeling came from books, at first. It came from the girls' stories by the writer L.M. Montgomery, who often inserted some sentences describing a snowy field in moonlight or a pine forest or a still pond mirroring the evening sky." 51 Warnqvist has shown that Swedish children's book writer Astrid Lindgren, author of Pippi Longstocking (1945), also was inspired by Montgomery's blossoming trees and made references to these in her stories. 52 One example is the short story "Under körsbärsträdet" ("Under the Cherry Tree") in Kajsa Kavat och andra barn (1950, "Brenda Brave and Other Children"), where "Ann is sitting under the cherry tree on a summer night, watching the swallows fly. The white, white blossoming cherry tree. It's so beautiful." 53 Sitting under the cherry tree and letting the beautiful spring setting send her imagination reeling, Lindgren's Ann comes across as a projection of Montgomery's Anne. Not only do they share the same name (apart from the missing -e); Lindgren's Ann is also fanciful, chatty, romantic, and preoccupied with the idea of being an orphan.

Montgomery's own reading of William Wordsworth, Henry Wadsworth Longfellow, and Ralph Waldo Emerson may have intensified her response to nature, but since then countless young readers-and writers-worldwide have learned from Anne and Emily and Valancy how to thrill to the sight of apple blossoms or forest ferns or spires of firs. Montgomery's heroines see the humanized natural landscape of Prince Edward Island through the eye of the imagination. Montgomery's readers are taught to see it that way too and name what they see wherever they are. It is a way of looking at the world portable beyond Avonlea.

Back to top

\section{In Conclusion: Reading and the Emotional World of L.M. Montgomery}


This study of Montgomery readers has been made possible by the very phenomenon that we seek to understand in this article: her enduring popularity with readers that has lasted for over a century. A list prepared by the Utica Public Library in 2012 of “The 50 All-Time Best Selling Works of Fiction" starts off with Don Quixote (1605) and descends through the list from A Tale of Two Cities (1859), The Count of Monte Cristo (1814), The Lord of the Rings (1954), through six Harry Potter novels and some other titles to, at spot twenty: Anne of Green Gables. What explains the staying power of the Montgomery books when so many other bestsellers have fallen into oblivion? For the answer, we turn our attention to the two elements in the reading transaction - the Montgomery readers and the books-and to the bond that connects them.

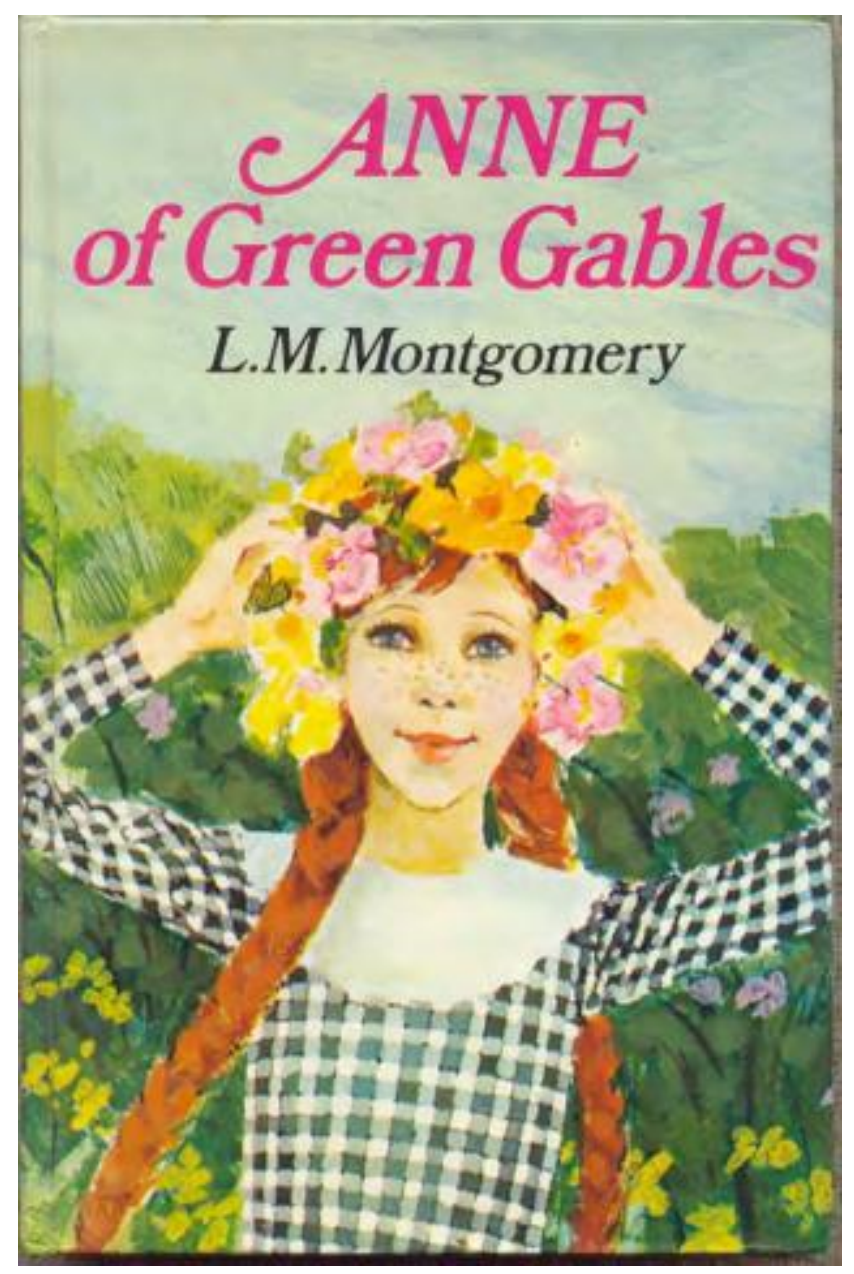

Book cover of Anne of Green Gables. 1979. KindredSpaces.ca, 001 AGGAR. 
What now can we say about the readers? As noted earlier, the subset of Montgomery readers in the Canadian avid-reader study strongly resembled each other and differed significantly from non-Montgomery readers, who described quite different ways of engaging with books. By and large, Montgomery fans are omnivorous readers who say they "devour" books, reading voraciously a great variety of different kinds of books at different levels of difficulty and demandingness. At those times when they choose to read or reread Montgomery, they are looking for a particular satisfaction associated with comfort, safety, and hope, and they may choose to do so at particularly stressful periods of their lives. The accounts of Canadian readers of Montgomery were almost indistinguishable from those of the Swedish readers, apart from the clues provided by national place names, people's names, references to schooling practices, and the like. Both sets of readers described in similar ways the first memorable encounter with Montgomery, expressed enthusiasm over what we have called the "series effect," described multiple rereadings of their favourite Montgomery books, and pointed to a strong female reading tradition and a female reading context. 54 Both sets of readers emphasized how they had been shaped in numerous ways by their reading of Montgomery's novels. They said that they wanted to get as close as possible to Anne or Emily and that they tried in their own lives to emulate the courage, goodness, kindness, love of nature, vivid imagination, and ambition to write that they saw represented by Montgomery characters. In short, the concordance between the responses of the Swedish and Canadian readers is striking. The similarities are undeniable, despite the different marketing strategies used in the two countries to recruit readers (initially the target audiences for Montgomery books were readers of all ages in North America and young adults in Sweden) and despite the two different methods we used in our study to solicit the reading experiences from readers.

Although we have discussed the ten emergent themes separately and one at a time, it is inescapably the case that, in the readers' experience, these themes are inextricably linked. In one way or another, all ten themes are connected by a powerful current of emotion, the quoted examples illustrating reading experiences remembered for their emotional impact. We know that different kinds of readers do variously seek out books with strong emotional effects-books that arouse anger over the world's corruption and inequity, books that cause readers' hearts to race in suspense, books that fill readers with a menacing sense of dread, and so on. Montgomery readers, by contrast-at least at the times in their lives when they seek out Montgomery books-are drawn to the books because they offer what Felski calls 
recognition and enchantment. 55 These readers are looking for comfort and reassurance and a reading experience that gives them hope and a sense of empowerment. They find this desired emotional experience through stories of the redemptive power of love in which, for example, Anne, through her goodness and loving nature, transforms the world around her, reawakens frozen Marilla to new life and joy, and finds for Anne herself an education, a new family, and a home. When readers say that they want to live in Montgomery's fictional world, they mean that, for a time, they want to take up residence in a world where such changes are possible-for the characters and for themselves.

The emotional impact of a Montgomery book on readers is salient during all three phases of reading:

- pre-reading, which are the factors that come before reading, such as how the reader learned about and got access to the book (a gift perhaps? a recommendation randomly chosen from a Girl Guide leader's list?) and the elements in the reader's life situation that prompted the reader to read the book;

- the time of reading itself, when the reader is engaged in reading or rereading and the focus is on the reading experience itself; and

- post-reading, when the reader keeps the book alive in memory, reflects on the book, may be influenced or changed by reading the book, and may recommend the book to others. 56

It is because Montgomery readers find her books so powerfully affecting that they so clearly remember their first encounter with Anne; that they want to read and reread all the books and pass them along to later generations; and that they want to be or be like Anne or Emily. The emotional impact of Montgomery's characters echoes through defining moments of their lives and informs important life choices.

Warnqvist has, for example, explored the empowering potential in Montgomery's books from a gender perspective and pointed to the emancipatory potential of these books when read by girls at a young age. Readers affirm this potential in the many statements quoted above concerning how Anne and Emily were essential in their making important life decisions, such as the choice of education or profession or both. 57 The same study by Warnqvist shows that the physical books often become a repository for memory and for emotional connection. $\underline{58}$ 
Kannas comes to similar conclusions in her analysis of the responses of Finnish readers to Montgomery. 59 She makes the case that there is "something deeply emotion-driven in Montgomery's books that permeates the [readers'] accounts of reading them" and gives the readers "such a close relationship with them that reading becomes an emotional experience." She summarizes that "it is not the content of the text but the long relationship the readers have with the books and the characters that matter the most in establishing the emotional effect." 60 To illustrate this "long relationship," we give the last word to a Swedish reader, Solveig Thun Johansson (born in 1936, retired), who in her reading experience gave perhaps the best example of the depth of the emotional connection that a reader can feel to a Montgomery book. It is not her own story she tells, but a story told to her by a family friend about a woman who turned to Montgomery during a terminal illness. Knowing that she was dying, this woman chose to spend her last days listening to her husband reading the Anne books:

The wife had been ill for a long time, and eventually she was too weak to read. Her husband would read her magazines and books. But towards the end, all she wanted him to read to her were the Anne books, and he read them to her many times, and listening to these well-known stories from her childhood and adolescence made her calm and relaxed. Returning to those settings made her feel safe.

\section{About the Authors:}

\section{Catherine Sheldrick Ross}

Catherine Sheldrick Ross, FRSC, is Professor Emerita and former Dean of the Faculty of Information and Media Studies (FIMS) at Western. Interested in texts, authorship, readers, and the reading experience, she has published numerous articles on Canadian literature, librarianship, readers' advisory, and leisure reading as well as interviews that she conducted with Canadian writers, including Margaret Atwood, Clark Blaise, Dennis Lee, Jean Little, Alice Munro, and James Reaney. A long-standing research focus has been the study of the pleasure-reading experience, based on open-ended, qualitative interviews of avid readers. Her recent books on leisure reading are The Pleasures of Reading: A Booklover's Alphabet (2014) and the coauthored Reading Still Matters: What the Research Reveals About Reading, Libraries, 
and Community (2018). In 2013, she received the Margaret E. Munroe Award given by the American Library Association for "significant contributions to library adult services."

\section{Åsa Warnqvist}

Assa Warnqvist, Ph.D., is the Research Manager and Director of the Swedish Institute for Children's Books and affiliated with Linneaus University. Her research has primarily been focused on Canadian writer L.M. Montgomery, the Swedish children's book market, gender studies, and normativity studies. Warnqvist's research project "L.M. Montgomery in Sweden" focuses on Montgomery's success in Sweden and combined studies of the books' publishing history with reader response. It has been largely funded by the Swedish Research Council. Several articles in Swedish and English has been published within the project and more are to come. Warnqvist is the editor of Barnboken: Journal of Children's Literature Research, the only Swedish academic journal on children's literature. She is also a member of the IRSCL executive board, congress convenor of the IRSCL Congress 2019, and vice-president of IRSCL. Warnqvist coordinated the international conference "L.M. Montgomery Writer of the World" (Uppsala, Sweden) in 2009 together with Dr. Gabriella Åhmansson. During 2011-2013 she was the Visiting Scholar at the L.M. Montgomery Institute, UPEI.

Banner image derived from: Canadian and Swedish Flags, 2020.

- 1 Ross, "Readers Reading"; Warnqvist, "Anne"; Warnqvist, “Flickan"; Warnqvist, “I Experienced”; Warnqvist, “'Under körsbärsträdet'”; Warnqvist, forthcoming.

- 2 Akamatsu, "Japanese Readings."

- 3 Ahola and Koskimies, "Love and Controversy."

- 4 Ahola and Koskimies, Uuden Kuun.

- $\underline{5}$ Kannas, "'Emily Equals Childhood.'”

- 6 Ross, The Pleasures 153.

- 7 Montgomery, BC 38.

- 8 Felski, Uses of Literature 22.

- 9 Ross, McKechnie, and Rothbauer, Reading Still Matters 25-37.

- 10 Ross, McKechnie, and Rothbauer, Reading Still Matters 25-37.

- 11 Rosenblatt, Literature as Exploration 30-31.

- 12 Ross, McKechnie, and Rothbauer 137-46. 
- 13 Ahola and Koskimies, Uuden Kuun.

- 14 The translations were made by Hanna Liljeqvist.

- 15 Ross, McKechnie, and Rothbauer 138-139.

- 16 De första resultaten 11.

- 17 Ross, The Pleasures 165-171.

- 18 Ross, The Pleasures 86.

- 19 Ross, The Pleasures 83-91.

- 20 McKenzie, "Patterns, Power, and Paradox" 132.

- 21 Warnqvist, “I Experienced" 229-234.

- 22 See Ahola and Koskimies, "Love and Controversy" 239; Warnqvist, "Flickan"; Warnqvist, forthcoming.

- 23 See Ahola and Koskimies, "Love and Controversy" 239.

- 24 See Kannas 118; Ross, The Pleasures 29; Warnqvist, "I Experienced" 235; Warnqvist, forthcoming.

- $\underline{25}$ For a thorough discussion on this, see Warnqvist, "Flickan" 29-32; Warnqvist, forthcoming.

- 26 Demographic information about the readers was collected at the time of the interview or submission of the written account.

- 27 Felski chapter 2 .

- 28 As also noted by Kannas 125 .

- 29 In excerpts from interviews, I is the interviewer and $\mathrm{R}$ is the respondent.

- 30 See Reimer et al., "Introduction."

- 31 See Warnqvist, "Flickan" 36; Warnqvist, forthcoming.

- 32 Ross, "Finding without Seeking."

- 33 Felski.

- 34 Felski chapter 1.

- 35 Montgomery, SJ3: 168 (9 March 1924).

- 36 Kannas 130.

- 37 Warnqvist, "Flickan som läsare" 34; Warnqvist, forthcoming.

- 38 See Warnqvist, "Flickan" 34; Warnqvist, forthcoming.

- 39 Ross, "Finding Without Seeking"; see also Felski, chapter 1.

- 40 Akamatsu 209.

- 41 Ahola and Koskimies, "Love and Controversy" 239.

- $\underline{42}$ Ross, "Finding Without Seeking."

- 43 See Ross, "Finding Without Seeking"; Ahola and Koskimies, "Love and Controversy" 239; Warnqvist "Flickan"; Warnqvist, forthcoming.

- 44 Gold, Read for Your Life 110. 
- 45 Frye, The Secular Scripture.

- 46 See Kessler, "L.M. Montgomery."

- 47 Waterston, Magic Island.

- 48 Urquhart, L.M. Montgomery 143, 150.

- 49 Rémi, "From Green Gables."

- 50 See Warnqvist, "I Experienced" 232-233.

- 51 Munro, The View 198.

- 52 Warnqvist, "'Under körsbärsträdet.'”

- 53 Lindgren, Kajsa Kavat 104.

- 54 See Warnqvist, "Flickan" 34; Warnqvist, forthcoming.

- $\underline{55}$ Felski.

- 56 Ross, The Pleasures 16-22.

- 57 Warnqvist, "Flickan"; Warnqvist, forthcoming.

- 58 See Warnqvist, "Flickan" 36; Warnqvist, forthcoming.

- 59 Kannas.

- 60 Kannas 124.

Back to top

\section{Article Info}

Copyright: Catherine Sheldrick Ross and Åsa Warnqvist, 2020. This work is licensed under a Creative Commons Attribution 4.0 International License (Creative Commons BY 4.0), which allows the user to share, copy and redistribute the material in any medium or format and adapt, remix, transform and build upon the material for any purpose, even commercially, PROVIDED the Licensor is given attribution in accordance with the terms and conditions of the CC BY 4.0.

Peer reviewed

Yes

\section{Works Cited}

Ahola, Suvi, and Satu Koskimies, editors. Uuden Kuun ja Vihervaaran tytöt: Lucy M. Montgomeryn Runotyttö- ja Anna-kirjat suomalaisten naislukijoiden suosikkeina [The Girls of New Moon and Green Gables: L.M. Montgomery's Emily and Anne Books as Favourites Among Finnish Female Readers]. Tammi, 2005. 
---. "Love and Controversy for Over Eighty Years: Anne, Emily, and Finnish Women: An Interview." Storm and Dissonance: L.M. Montgomery and Conflict, edited by Jean Mitchell, Cambridge Scholars Publishing, 2008, pp. 238-244.

Akamatsu, Yoshiko. "Japanese Readings of Anne of Green Gables." L.M. Montgomery and Canadian Culture, edited by Irene Gammel and Elizabeth Epperly, $U$ of Toronto P, 1999, pp. 201-212.

Collinson, Ian. Everyday Readers: Reading and Popular Culture. Equinox Publishing, 2009.

De första resultaten från Nordicom-Sveriges Mediebarometer 2017: Mars 2018 [The First Results from Nordicom-Sweden's Media Barometer 2017: March 2018]. Nordicom, Gothenburg U, 2018, http://www.nordicom.gu.se/sites/default/files/mediefaktadokument/Mediebarometern/Mbar Tema ra/mediebarometern 2017 de forsta resultaten.pd

Felski, Rita. Uses of Literature. Blackwell Publishing, 2008.

“The 50 All-Time Best Selling Works of Fiction." Utica Public Library, 2012, https://www.uticapubliclibrary.org/resources/literature-and-film-guides/50-all-timebest-selling-works-of-fiction/.

Fry, Donald. Children Talk About Books: Seeing Themselves as Readers. Open UP, 1985.

Frye, Northrop. The Secular Scripture: A Study of the Structure of Romance. Harvard UP, 1976.

Gold, Joseph. Read for Your Life: Literature as a Life Support System. Fitzhenry \& Whiteside, 1990.

Kannas, Vappu. “'Emily Equals Childhood and Youth and First Love': Finnish Readers and L.M. Montgomery's Anne and Emily books." Reading Today, edited by Heta Pyrhönen and Janna Kantola. UCL P, 2018, pp. 118-131, http://discovery.ucl.ac.uk/10041155/1/Reading-Today.pdf.

Kessler, Deirdre. "L.M. Montgomery and the Creation of Prince Edward Island." L.M. Montgomery and Canadian Culture, edited by Irene Gammel and Elizabeth Epperly, 
U of Toronto P, 1999, pp. 229-212.

Lindgren, Astrid. Kajsa Kavat och andra barn [Brenda Brave and Other Children]. Rabén \& Sjögren, 1950.

Long, Elizabeth. Book Clubs: Women and the Uses of Reading in Everyday Life. U of Chicago $\mathrm{P}, 2003$.

Mackey, Margaret. One Child Reading: My Auto-Bibliography. U of Alberta P, 2016.

McKenzie, Andrea. "Patterns, Power, and Paradox: International Book Covers of Anne of Green Gables across a Century." Textual Transformations in Children's Literature: Adaptations, Translations, Reconsiderations, edited by Benjamin Lefebvre, Routledge, 2013, pp. 127-153.

Montgomery, L.M. 1926. The Blue Castle. Dundurn P, 2006.

---. The Selected Journals of L.M. Montgomery. Edited by Mary Rubio and Elizabeth Waterston, Oxford UP, 1985-2004. 5 vols.

Munro, Alice. The View from Castle Rock. McClelland and Stewart, 2006.

Radway, Janice. Reading the Romance: Women, Patriarchy and Popular Literature. U of North Carolina P, 1984.

Reimer, Mavis, Nyala Ali, Deanna England, and Melanie Dennis Unrau. "Introduction: The Compulsion to Repeat." Seriality and Texts for Young People: The Compulsion to Repeat, edited by Mavis Reimer et al., Palgrave Macmillan, 2014, pp. 1-33.

Rémi, Cornelia. "From Green Gables to Grönkulla: The Metamorphoses of Lucy Maud Montgomery's Anne of Green Gables in Its Various Swedish Translations."

Barnboken: Journal of Children's Literature Research, vol. 42, 2019, pp. 1-36, http://dx.doi.org/10.14811/clr.v42i0.447.

Rosenblatt, Louise. 1938. Literature as Exploration. 5th ed., Modern Language Association, 1995.

Ross, Catherine Sheldrick. "Finding Without Seeking: The Information Encounter in the Context of Reading for Pleasure." Information Processing and Management, vol. 35, 1999, pp. 783-799. 
---. The Pleasures of Reading: A Booklover's Alphabet. Libraries Unlimited, 2014.

---. "Readers Reading L.M. Montgomery." Harvesting Thistles: The Textual Garden of L.M. Montgomery, Essays on Her Novels and Journals, edited by Mary Henley Rubio, Canadian Children's P, 1994, pp. 23-35.

Ross, Catherine Sheldrick, Lynne (E.F.) McKechnie, and Paulette M. Rothbauer. Reading Still Matters: What the Research Reveals About Reading, Libraries, and Community. Libraries Unlimited/ABC-CLIO, 2018.

Urquhart, Jane. L.M. Montgomery. Penguin Canada, 2009.

Warnqvist, Åsa. "Anne på Grönkulla-'en af de nöjsammaste bekantskaper man kan göra': Utgivning och mottagande av L.M. Montgomerys verk i Sverige" ["Anne of Green Gables-'One of the Most Delightful Acquaintances One Could Make'": Publication and Reception of L.M. Montgomery's Work in Sweden"]. I litteraturens underland: Festskrift till Boel Westin, edited by Maria Andersson, Elina Druker, and Kristin Hallberg, Makadam, 2011, pp. 212-229.

---, editor. Besläktade själar: Läsupplevelser av Anne på Grönkulla [Kindred Spirits: Reading Experiences of Anne of Green Gables.]. BTJ förlag, 2009.

---. "Flickan som läsare: Exemplet Anne på Grönkulla” ["The Girl as Reader: The Case of Anne of Green Gables"]. Flicktion: Perspektiv på flickan i fiktionen, edited by Eva Söderberg, Maria Österlund, and Bodil Formark, Universus Academic P, 2013, pp. 29-41.

---. “'I Experienced a Light That Became a Part of Me': Reading Anne of Green Gables in Sweden." Anne Around the World: L.M. Montgomery and Her Classic, edited by Jane Ledwell and Jean Mitchell. McGill-Queen's UP, 2013, pp. 228-242.

---. “'Under körsbärsträdet sitter Ann': Dialogen med L.M. Montgomery i Astrid Lindgrens verk" ["'Under the Cherry Tree Sits Ann': The Dialogue with L.M. Montgomery in the Works of Astrid Lindgren"]. Nya läsningar av Astrid Lindgren, edited by Helene Ehriander and Martin Hellström, Liber, 2015, pp. 103-121.

---. Under review. "Anne of Green Gables and the Girl Reader: The Subversive and Emancipatory Potentials of Productive and Future-Oriented Girlhood Reading." L.M. Montgomery and Gender, edited by Holly Pike and Laura Robinson, McGill-Queen's UP. 
Waterston, Elizabeth. Magic Island: The Fictions of L.M. Montgomery. Oxford UP, 2008. 